د. ماجد مهلي قاسم القطوي

المجلد السابع والعشرون العلد (3)، سبتمبر 2021م ماجدي ماسمي الفوي

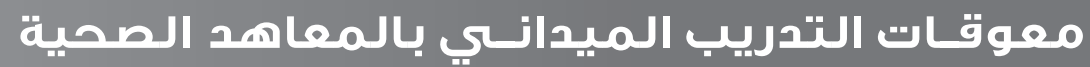

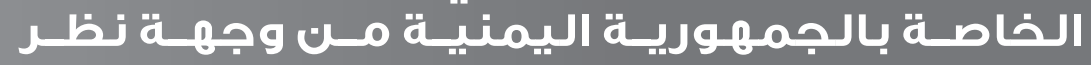
الطلبة البئية

الاسـتلام : 13/ يونيو / 2021

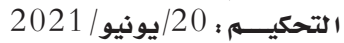

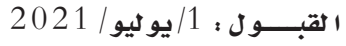

د. ماجد مهلبي قاسم القطوي)(1،)

(๑) 2021 University of Science and Technology, Yemen. This article can be distributed under the terms of the Creative Commons Attribution License, which permits unrestricted use, distribution, and reproduction in any medium, provided the original author and source are credited.

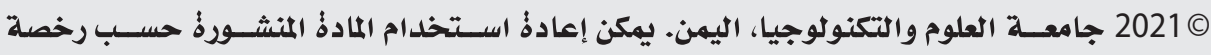
مؤسسة الششاع الإبلاعي شريطة الاستشهاد بالمؤلف والمجلة. 


\section{معوقات التدريب الميداني بالمعاهد الصحية الخاصة بالجمهورية اليمنية مـن وجهة نظر الطلبة الطمدة}

\section{الملخص:}

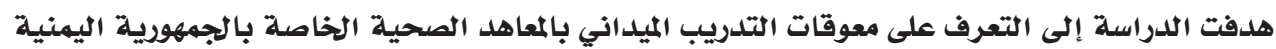

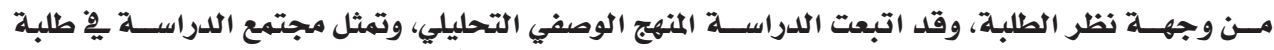

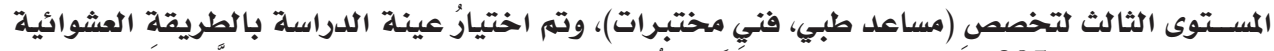

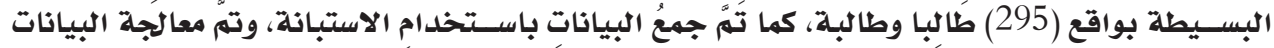

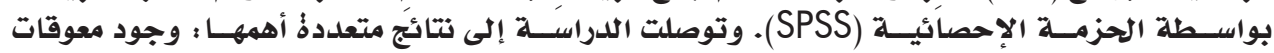

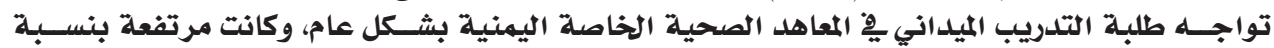

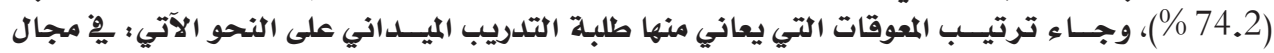

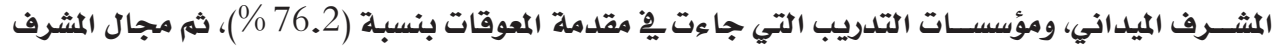

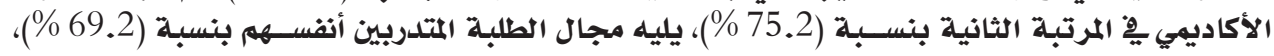

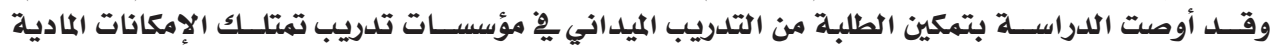

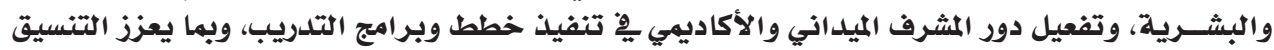
الفعال بين كافة أطراف العملية التدرية دوريبية الميرفي الكلمات المفتاحية : التدريب الميداني، المعاهد الصحية الخاصة، المعوقات. 


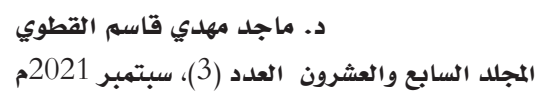

\title{
Field Training Obstacles at Private Health Institutes in Yemen from Students' Perspective
}

\begin{abstract}
:
This study aimed to identify obstacles to field training at private health institutes in Yemen from students' perspective. The study adopted the descriptive analytical method and used a questionnaire to collect relevant data from a sample of 295 male and female students who were randomly selected from level three students majoring in physician assistant and laboratory technicians, representing the study population. The collected data were processed by the SPSS package. The study results showed that a high percentage $(74.2 \%)$ of students faced obstacles in the field training at private health institutes. These obstacles can be rated as follows: field supervisor and training institutions (76.2\%); academic supervisor (75.2\%); and the trainees themselves (69.2\%). The study recommended enabling students to practice field training in the training institutions that have human and material resources, and activating the role of the field and academic supervisor in implementing training plans and programs in a way that enhances effective coordination between all stakeholders of the training process.
\end{abstract}

Keywords: field-training, obstacles, private health institutes. 


\section{المـقـدمة:}

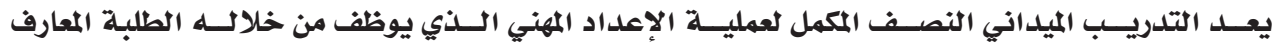

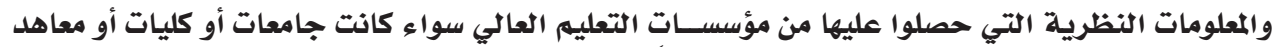

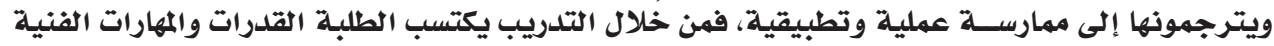

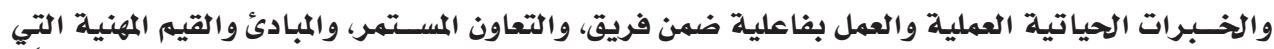

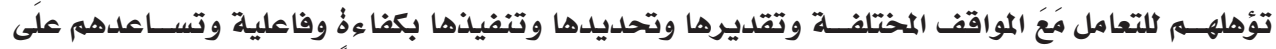
اتخاذ القرارات الصحيحة مئه حياتهم العملية والمستقبلية.

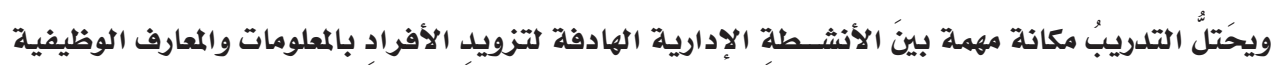

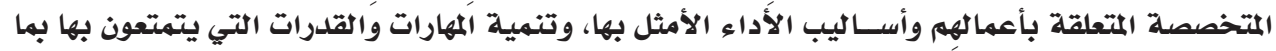

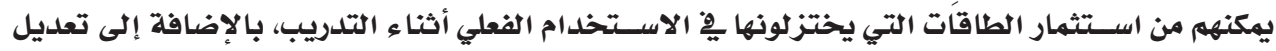

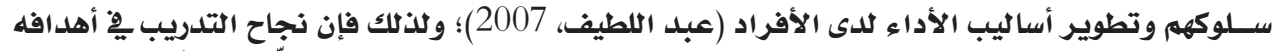

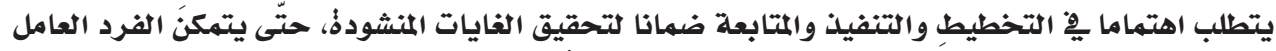

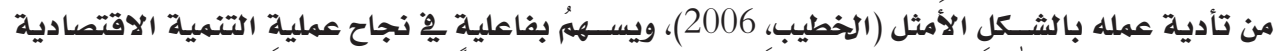

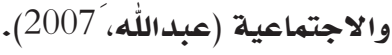

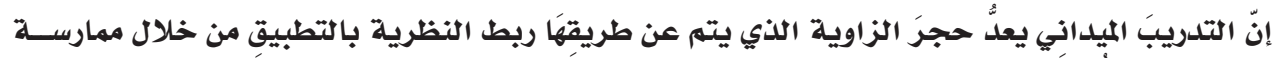

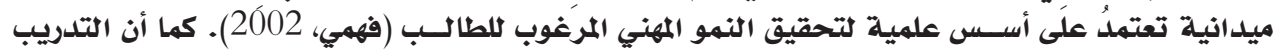

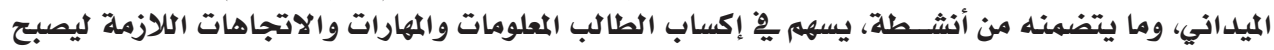

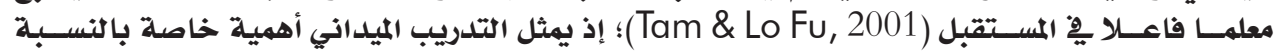

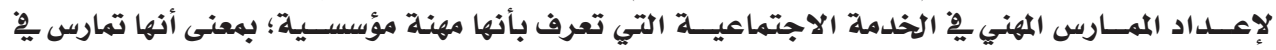

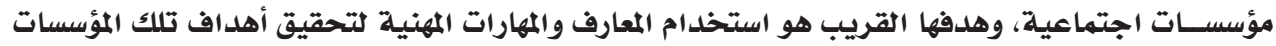

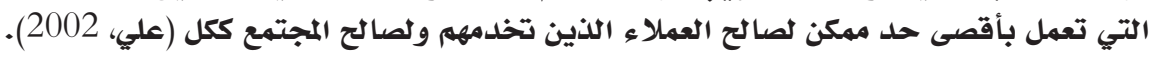

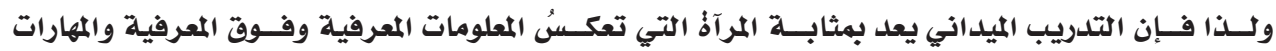

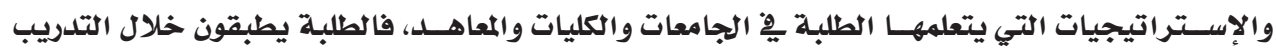

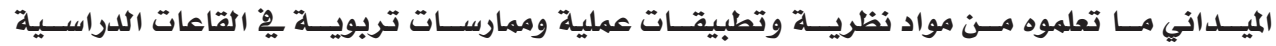
(الشوا، 2013).

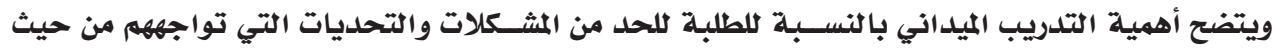

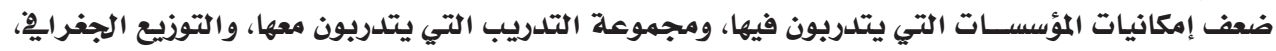

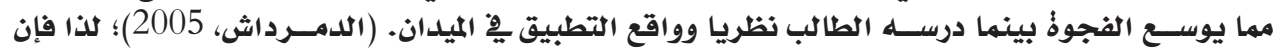

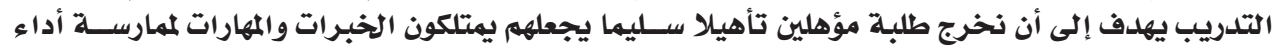

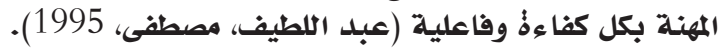

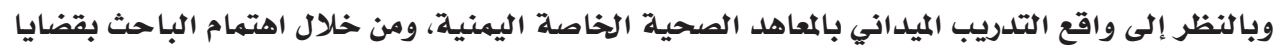

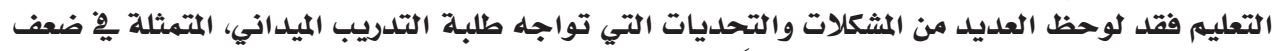

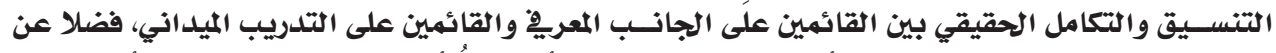

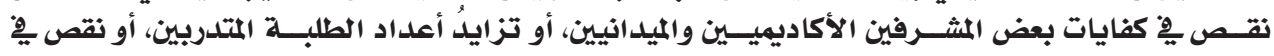

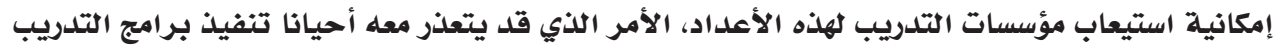

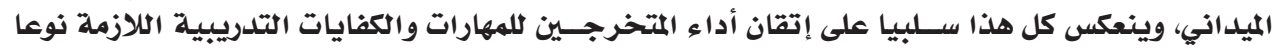

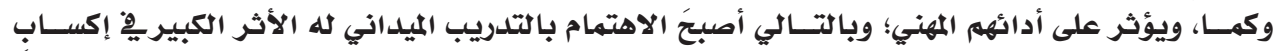

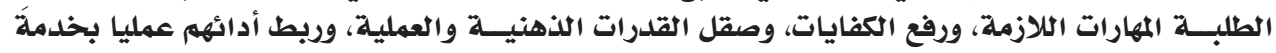

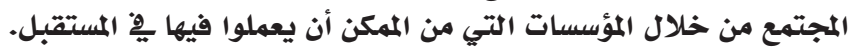


د. ماجد مهدي قاسم القطوي

المجلد السابع والعشرون العدد (3)، سبتمبر 2021 ماجديم المطوي

مفهوم التدريب الميلداني:

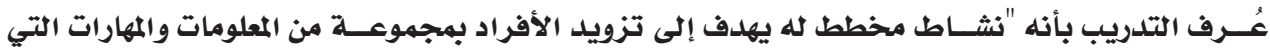

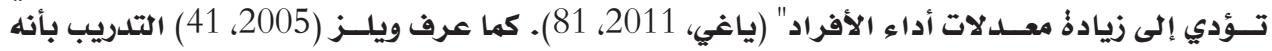

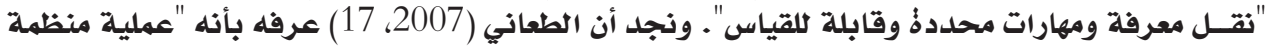

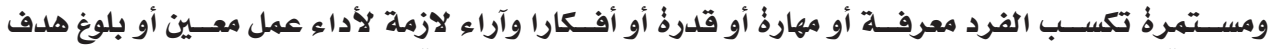

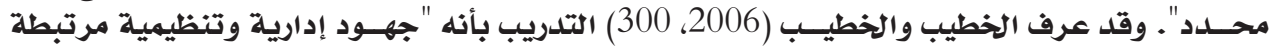

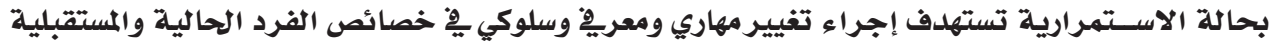

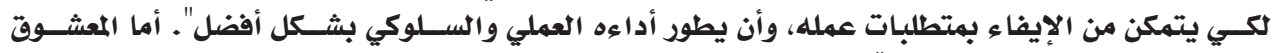

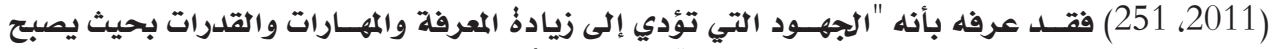

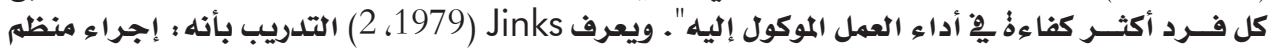

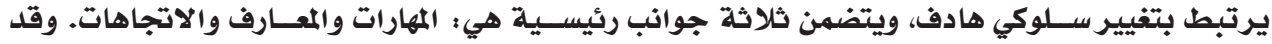

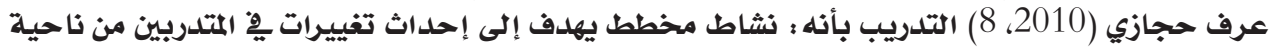

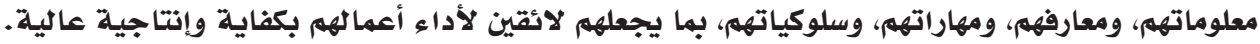

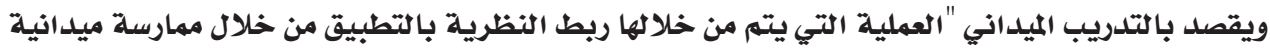

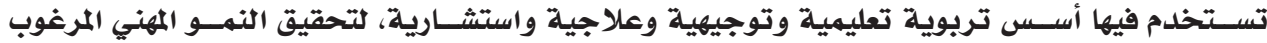

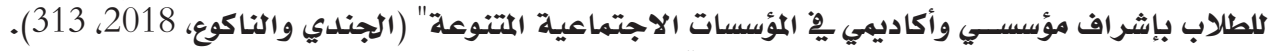

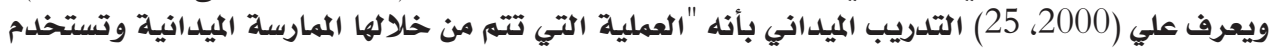

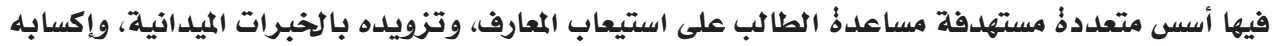

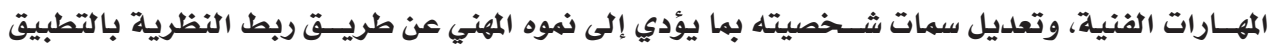

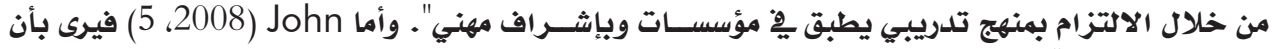

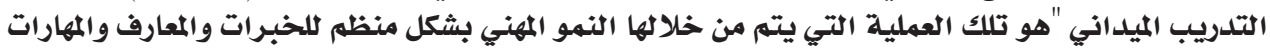

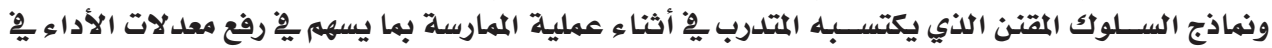

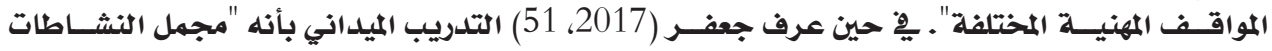

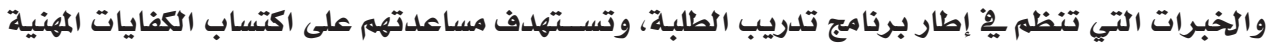

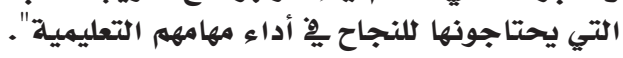
أهمية التلدريب الميداني:

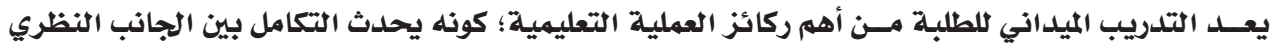

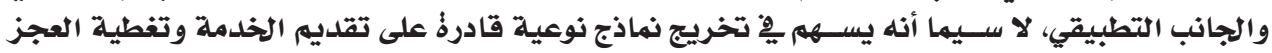

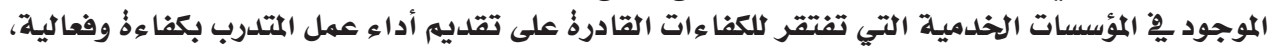

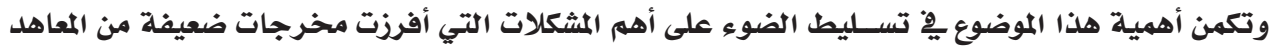

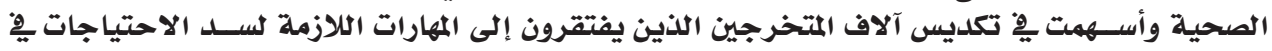
سوق العمل.

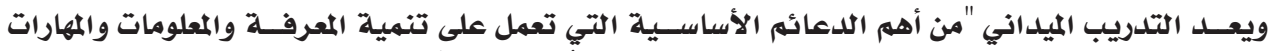

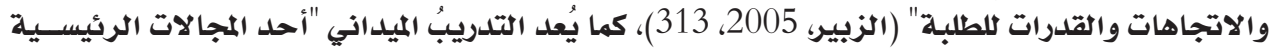

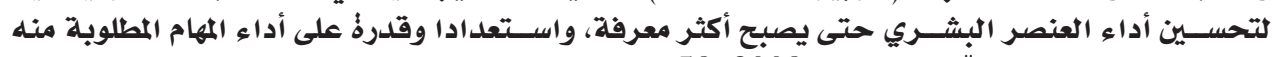

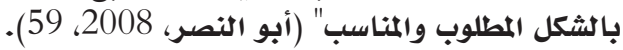

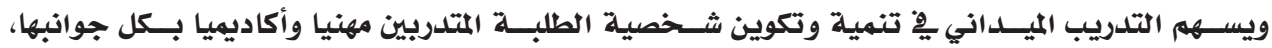

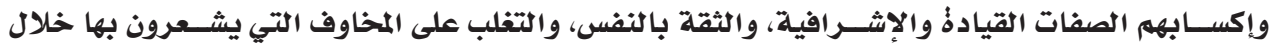

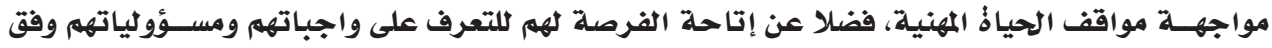
أسس علمية سليمة (بلابل، 2014). 
ويزيدُ من هذه الأهمية من الناحية العملية العوامل الآتية (كردي، 2010)؛

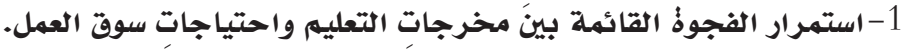

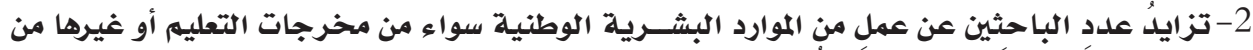

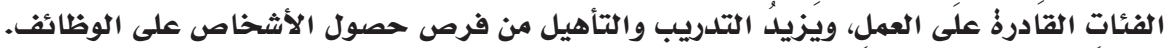

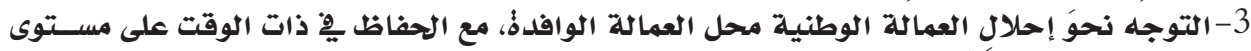

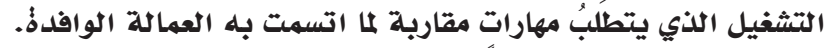

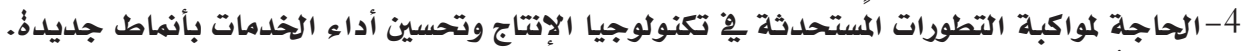

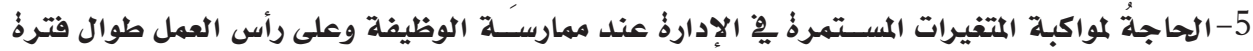

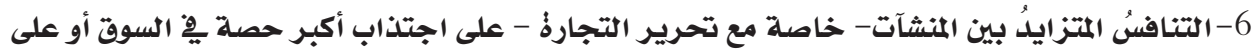

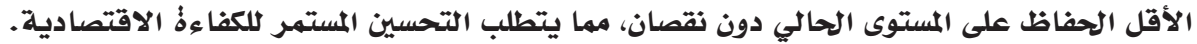

$$
\text { وهنا يمكن القول إن التدريب يحقق للمتدرب اكتساب الآتي: }
$$

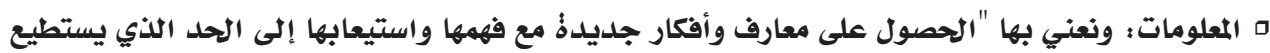

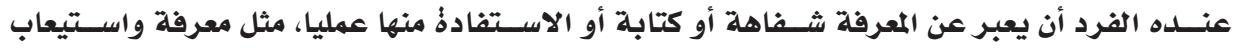

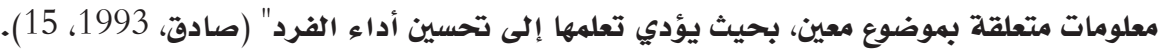

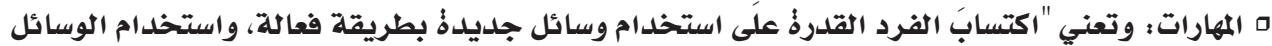

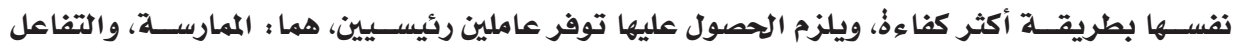

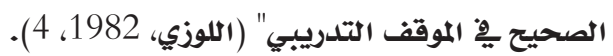

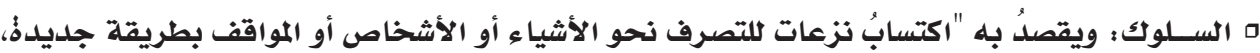

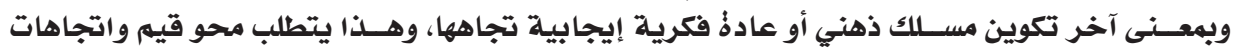

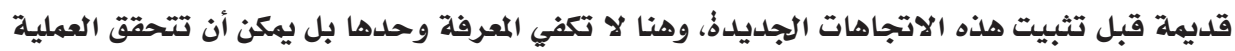

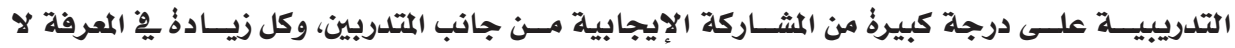

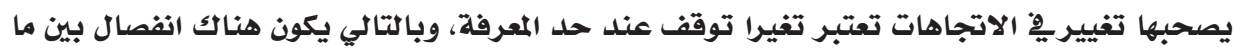

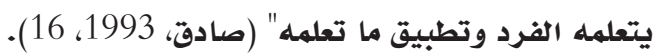

ه الخبرةٌ : ويختلف هذا المجال عن المجالات السابقة بحيث لا يمكن تعلمها داخل قاعة التدريب وإنما هي

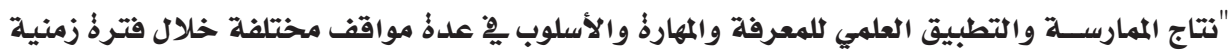

$$
\text { طويلة" ( حنفي، 1993، 58). }
$$

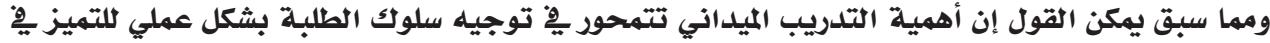

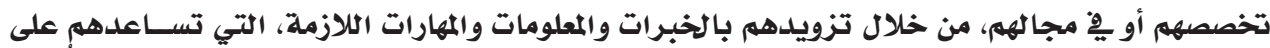

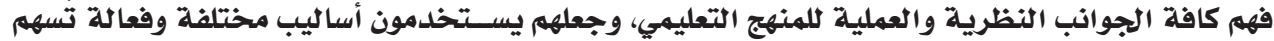

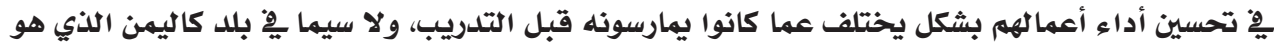

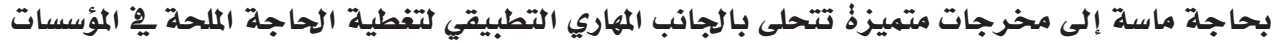

الخلدمية الصحية.

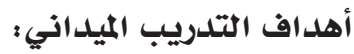

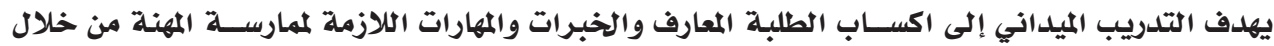

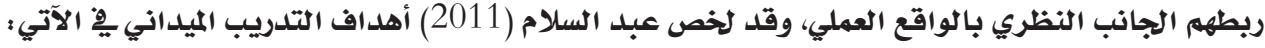
1- تطوير الاتجاهات والمعارف وإحداث تغييرات إيجابية ِِّ سلوكيات الأفراد واتجاهاتهم. 
د. ماجد مهدي قاسه القطوي

المجلد السابع والعشرون العدد (3)، سبتمبر 2021م فاسم الفطوي

2-تنمية قدرةٌ الطلبة على اســتخدام المعارف الصحيحة يِّ الممارســة، وزيادةٌ الفهم للنظريات والمبادئ المهنية التي درستّ.

3-تتهية المهارات والقدرةٌ على مواجهة المشكلات درسات المختلفة.

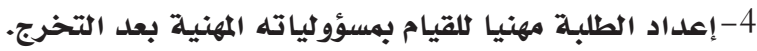

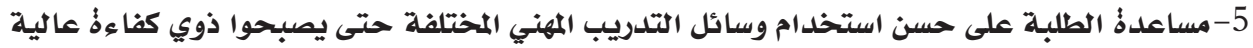

داخل المؤسسة.

6-تحسين أساليب وطرق الممارسة ودعم السلوكيات والاتجاهات البناءةٌ فِّة مجال علاقات العمل.

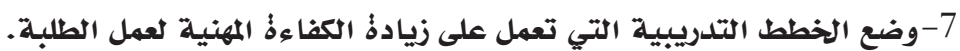

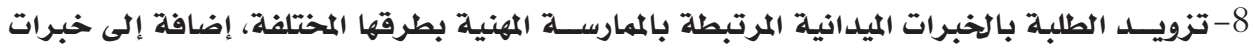

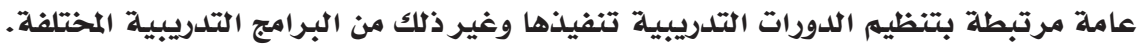

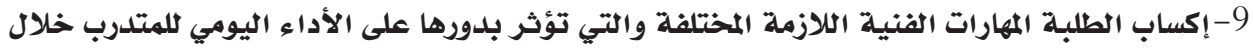

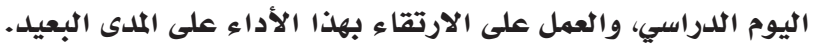

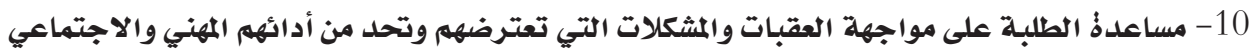

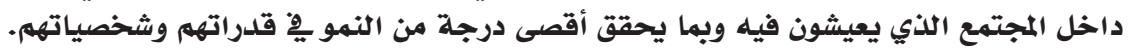

ويمكن تصنيف أهداف التدريب الميداني إلى ثلاثة جوانب أساسية (الحليبي وسالم، 2004) وهي:

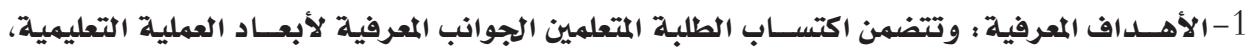
وقواعد العمل بها، وأدوار المعلم والإدارةٌ، والتعرف على اكتئ محتوى تعلم المقرر.

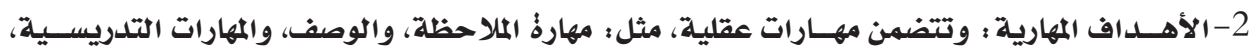

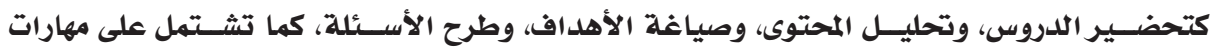

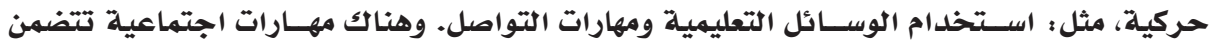

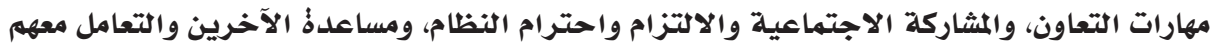

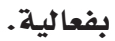

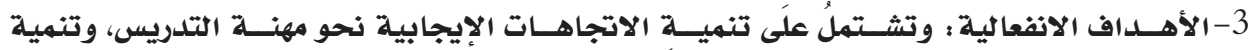

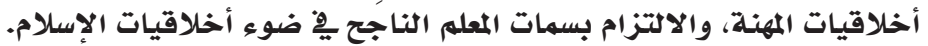

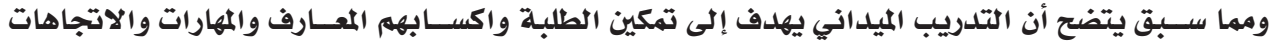

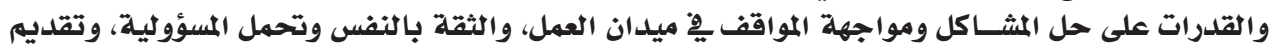

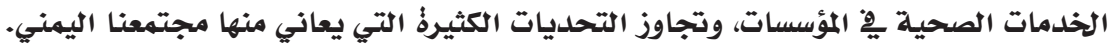

الإشراف على عملية التدريب الميداني (المهام - المسؤوليات) :

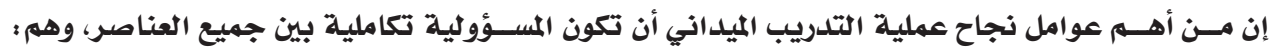

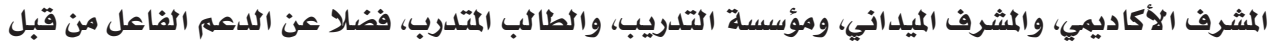

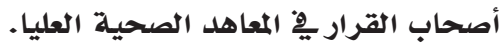
ويمكن الإشارةٌ إلى مهام ومسؤوليات المشاركين ِِّ عملية التدريب الميداني (رجب، 1988) على النحو الآتي؛

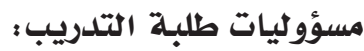

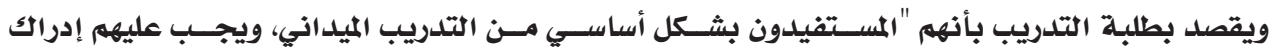

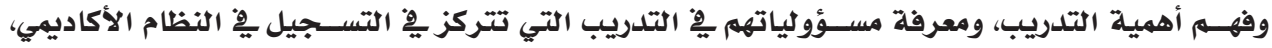

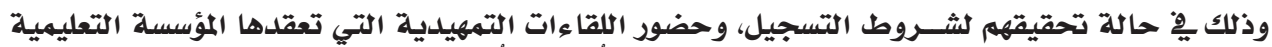

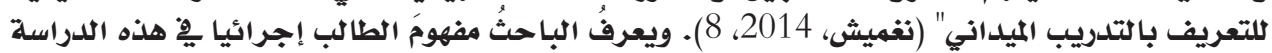

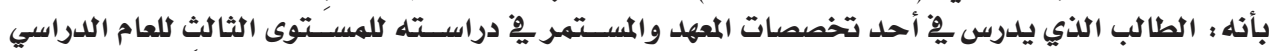

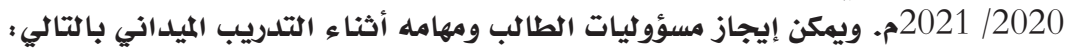




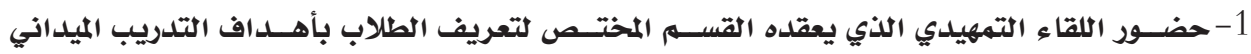
وأهميته.

2- اختيار مجال التلدريب والمؤسسة بما يتلاءم مع أهدافه وطموحاته وميوله وقدراته.

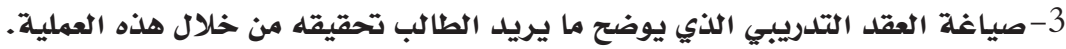

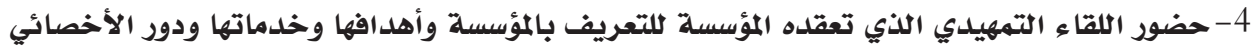
الاجتماعي.

5- الانتظام فٍِ الحضور إلى المؤسسة جميع الأيام المخصصة للتدريب ويٍِ المواعيد المحلددة.

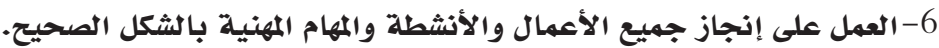

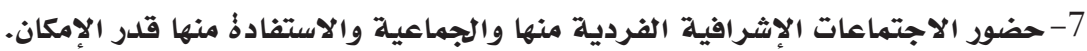

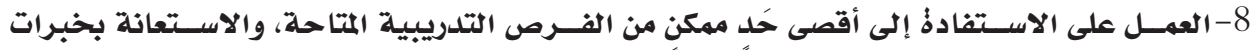
المشرفين.

9- الالتزام بأنظمة وقواعد وإجراءات المؤسسة وسياساتها وعلدم مخالفتها.

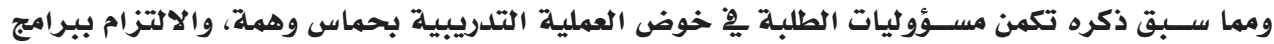

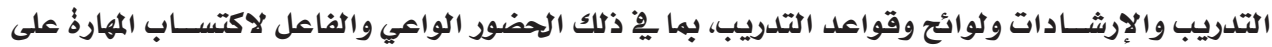

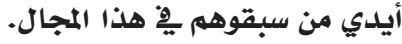

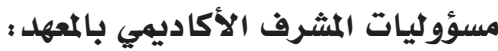

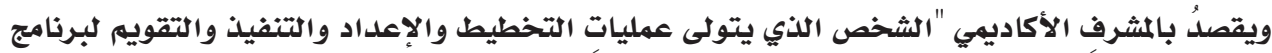

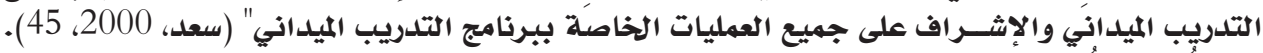

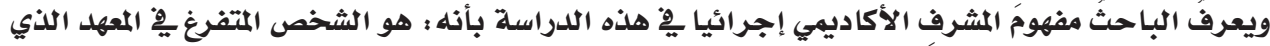

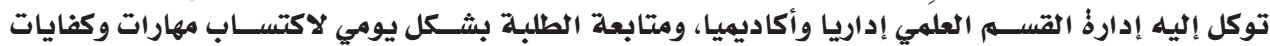

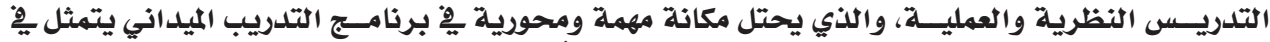

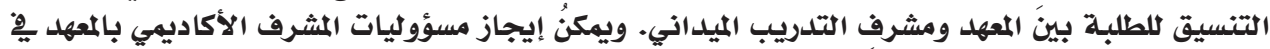

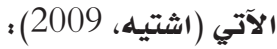
1- الحصول على موافقة إدارةٌ المؤسسة على تلدريب الطلاب بها وتيسير عملية استيعابهم مِِّاِ المؤسسات.

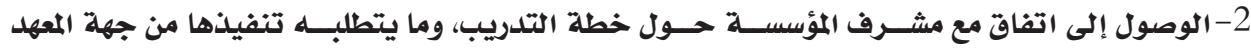
والمؤسسة تفصيلا وفق خطة المعهد يِّ التدريب، وطبيعة العمل يْ مؤسسة التدريب.

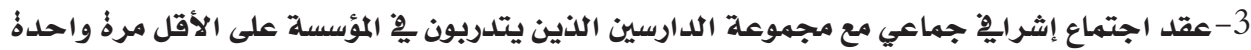

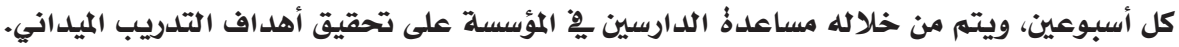

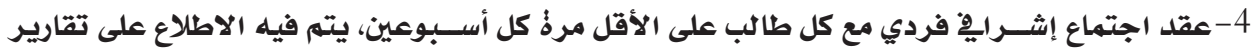
التدريب وسجله واعتماده.

5- ملاحظة أداء الدارسـين المسؤولياتهم التدريبية ومســاعدتهم على مواجهة أيلة صعوبات تواجههم فِ التلدريب. 6-شرح معايير تقويم الدراسين تفصيلا سواء لمشريٍ المؤسسة أم للدارسين أنفسهم وتوضيح ما هو متوقع

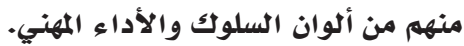
7- التقويم النهائي للدارسين بالتعاون مع مشرف المؤسسة ومديرها مِّف حلدود ما خصص لكل منهما.

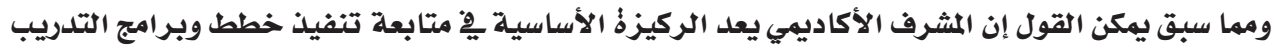

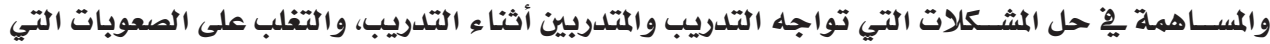

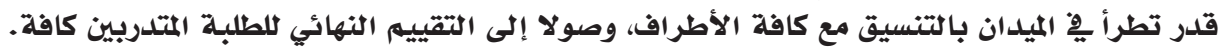




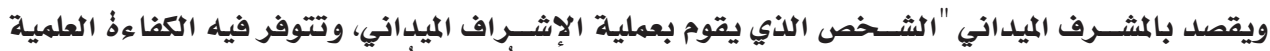

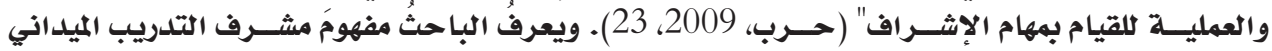

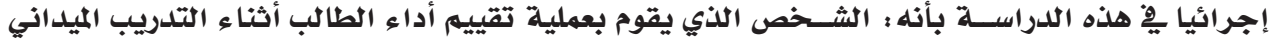

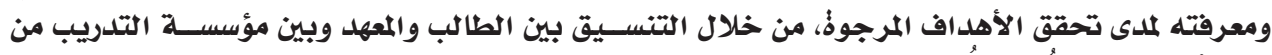

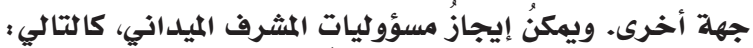

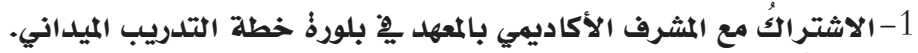

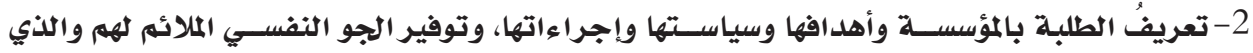

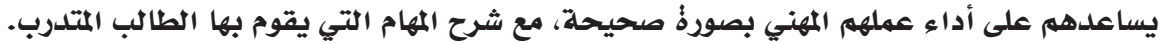

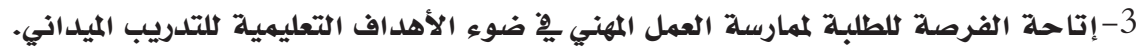

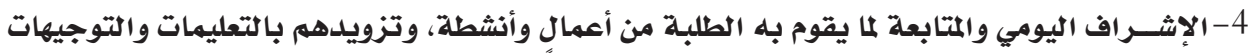
إنلازمة.

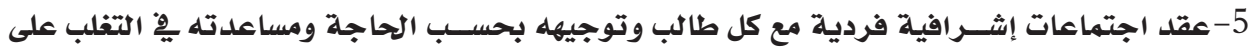

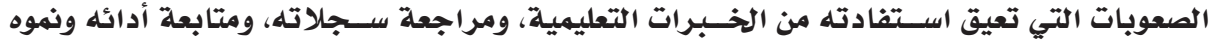
المهني.

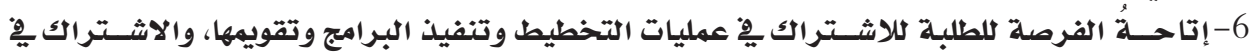
البحوث الميدانية التي تقوم بها المؤسسة.

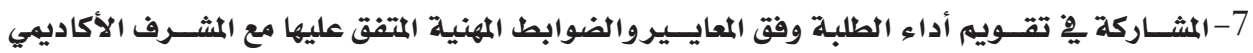

بالمعهد.

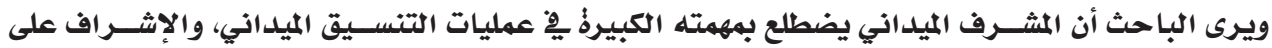

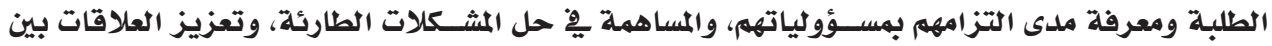
جميع الأطراف، والمشاركة يِّ التقييم النهائي للطلبة. مسؤوليات مؤسسة التدريب:

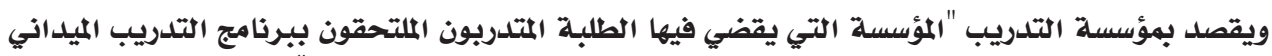

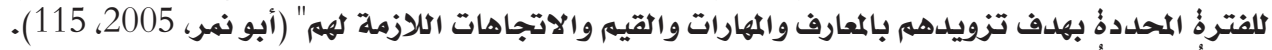

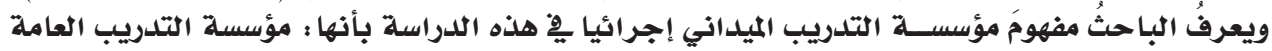

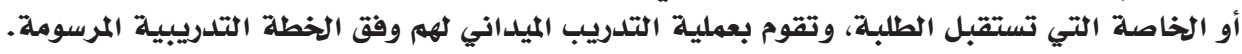
ويمكن إيجاز مسؤوليات مؤسسة التدريب (الخمشي، الرواف، وغز، 2005) على النحو الآتي:

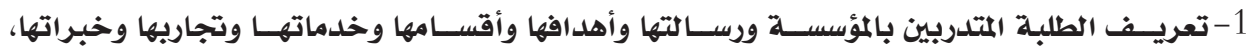
والعاملين بها. 2- اهتمام المؤسسة باختيار المتخصصين الاجتماعيين الذين يتولون مسؤولية الإشراف على التدريب.

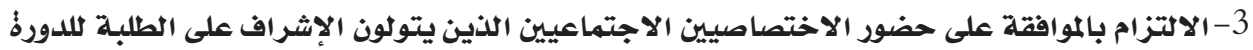

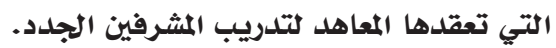

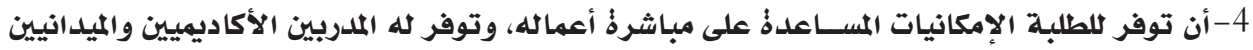
من ذوي الكفاءةٌ العالية.

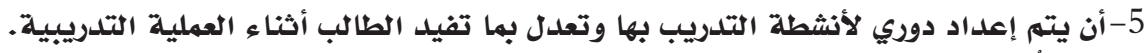

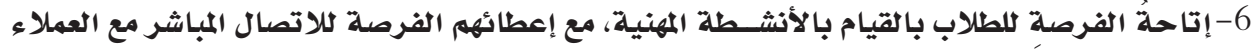

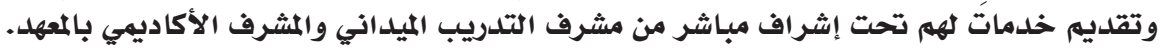
7- إخطار المعهد فورا ِِّ حالة وقوع أي تجاوزات من أحد الطلاب، أو أحد المشرفين. 


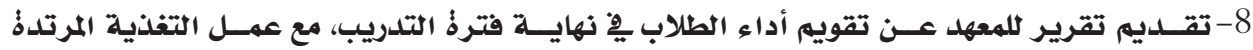

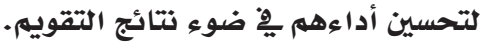

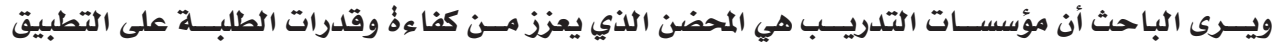

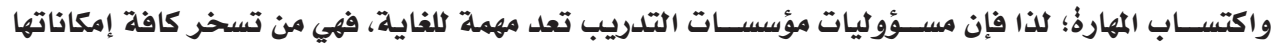

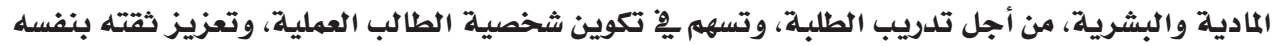

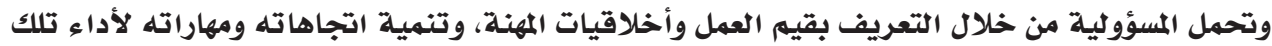
المهنة، وتهيئة الظروف المناسبة التي تشجعه على اختيار تلك المهنة التي تشبع ميوله ورغباته.

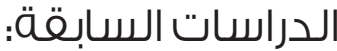

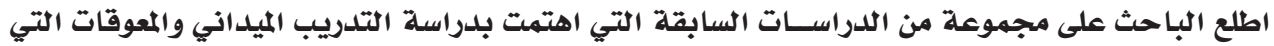
تواجه الطلبة، وقد عرضت أهم تلك الدراسات من الأحلدث إلى الأقلدم كالآتي:

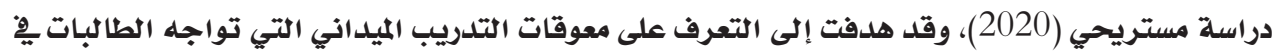

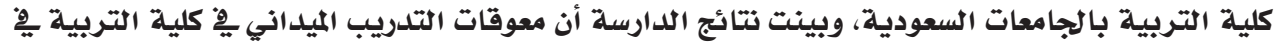

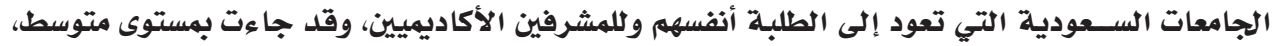

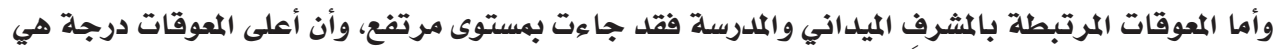

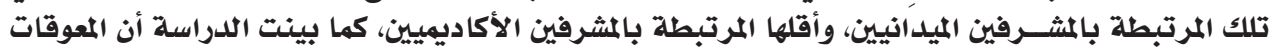
بشكل عام جاءت بمستوى متوسط.

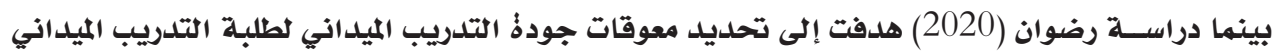

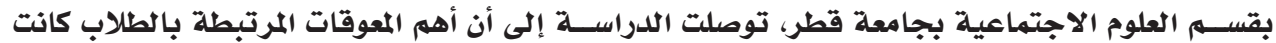

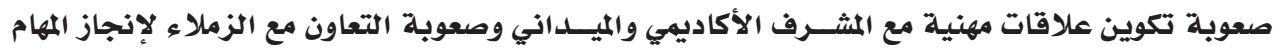

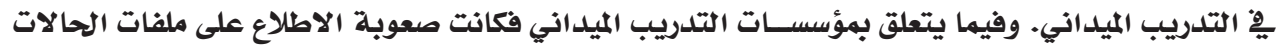

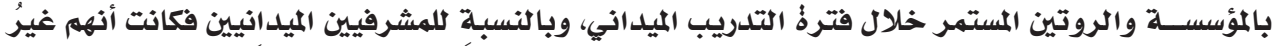

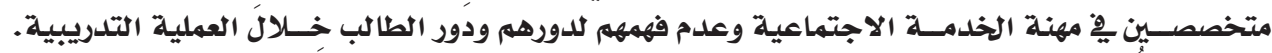

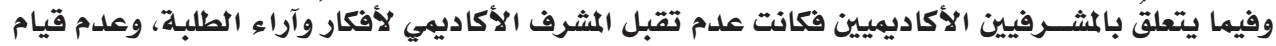

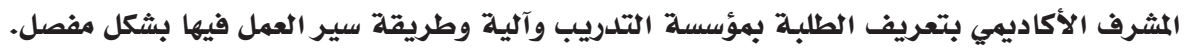

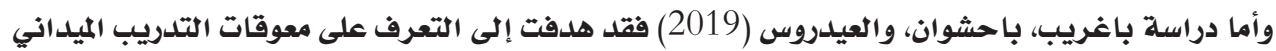

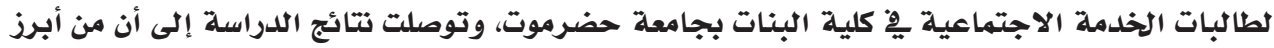

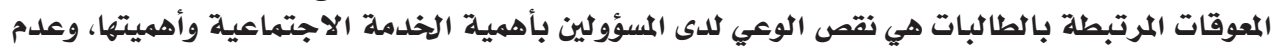

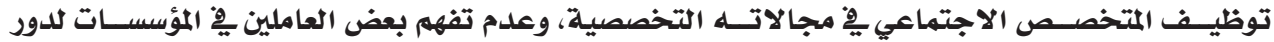

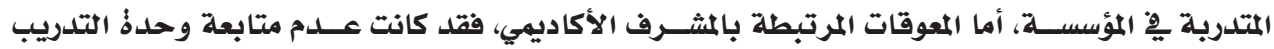

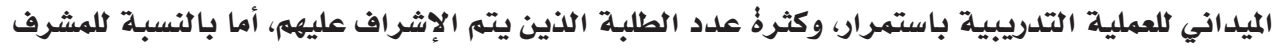

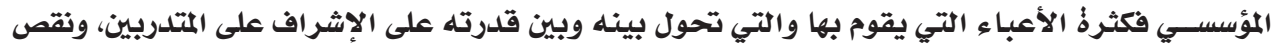

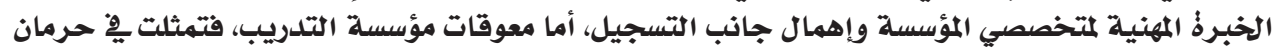

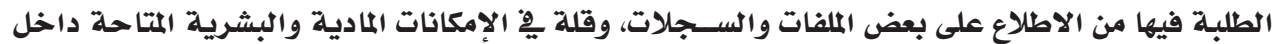

مؤسسات التلدريب.

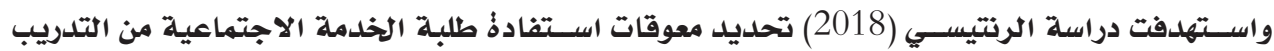

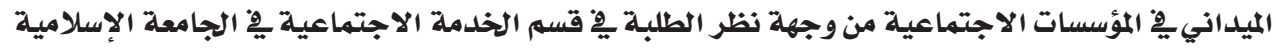

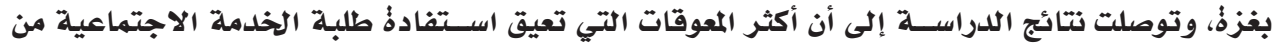

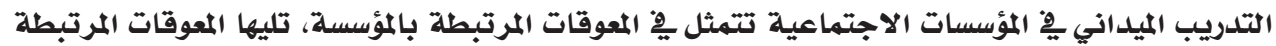

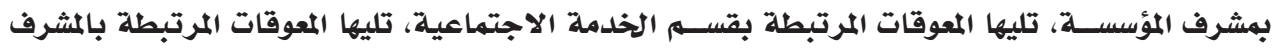
الأكاديمي، وأخيرا المعوقات المرتبطة باليطات الموقات المرتبطة 


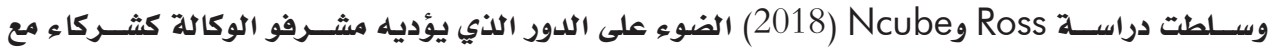

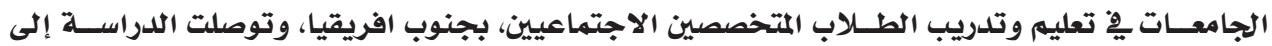

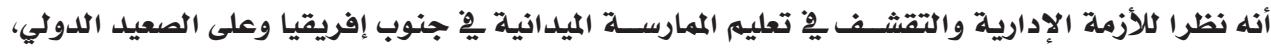

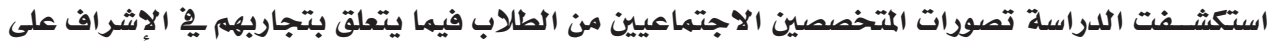

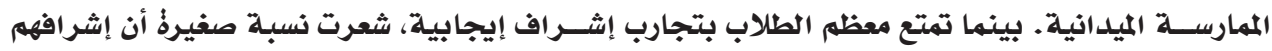

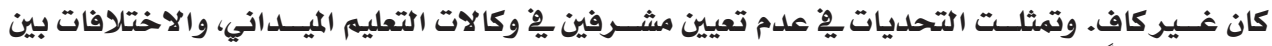

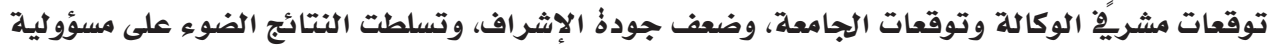

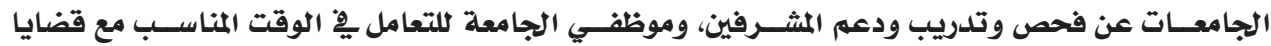
المشرف ومن ثم الإشراف عليهم.

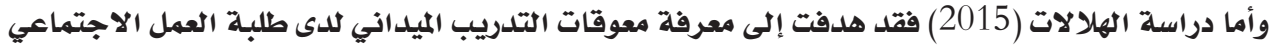

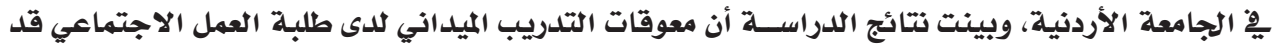

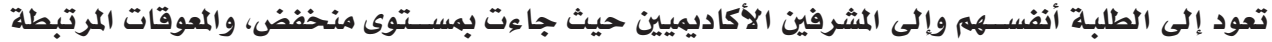

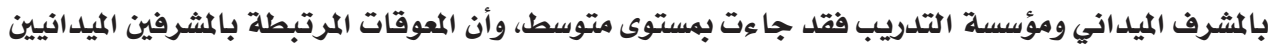

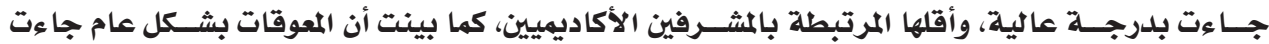
بمستوى متوسط.

أما دراســ Thaver (2012) فقد هلدفت إلى الكشف عن تجارب المتخصصين الاجتماعيين الذين يشرفون

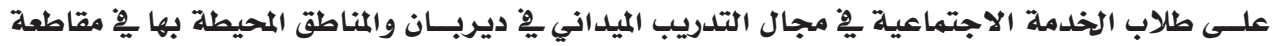

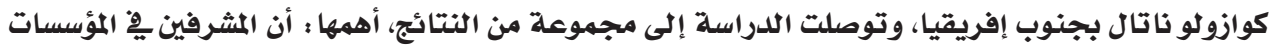

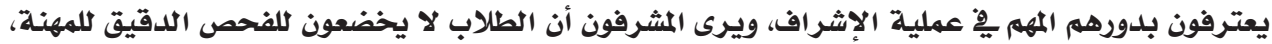

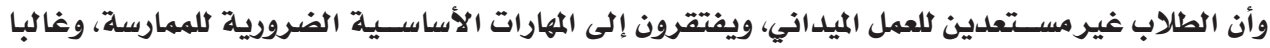

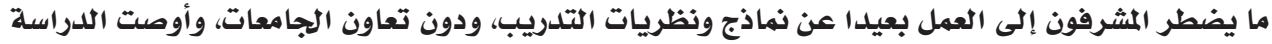

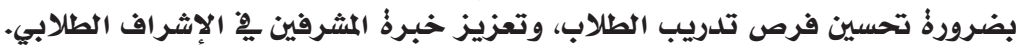

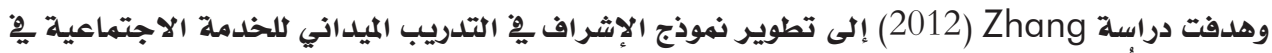

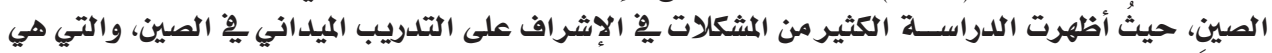

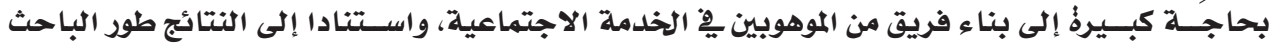

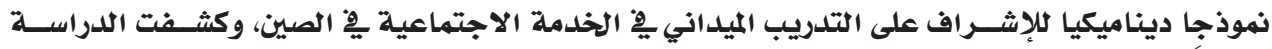

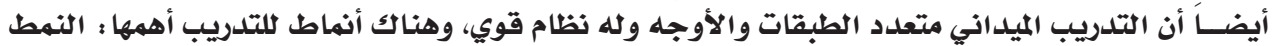
الفردي، والمؤسسي، ونهط المجتهمع ككل.

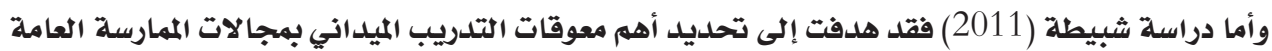

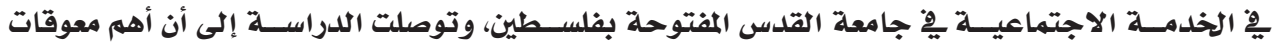

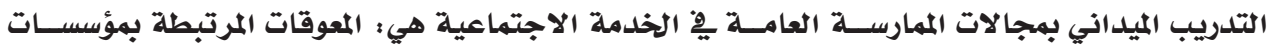

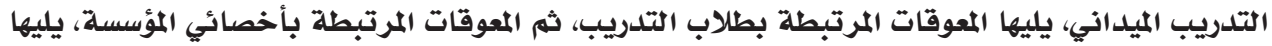

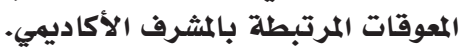

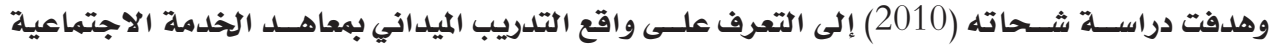

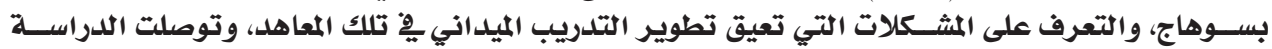

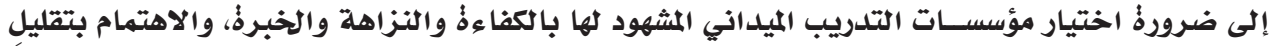

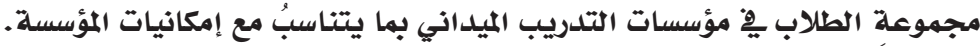

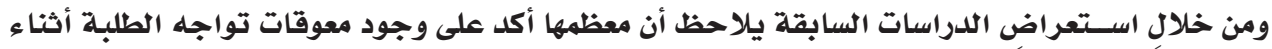

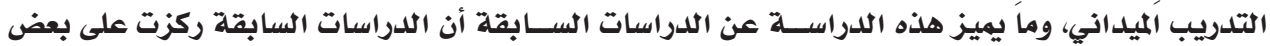




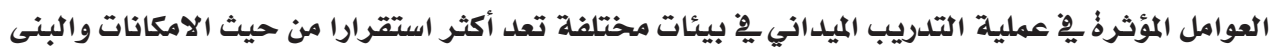

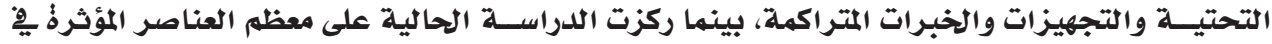

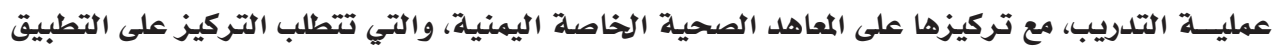

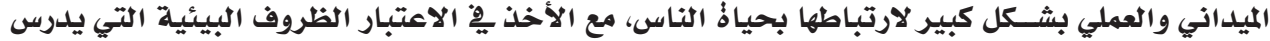

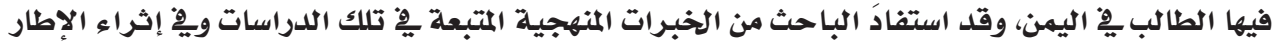

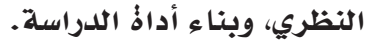

$$
\text { ملثكلة الدراسة: }
$$

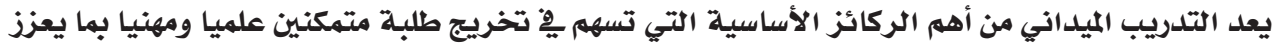

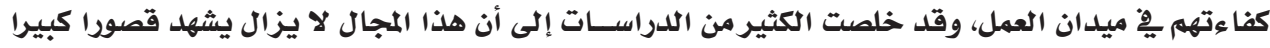

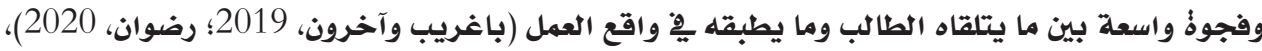

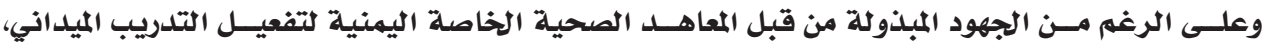

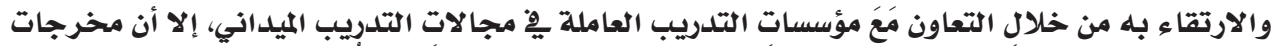

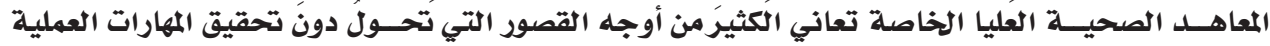

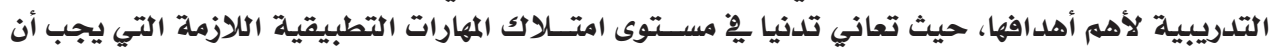

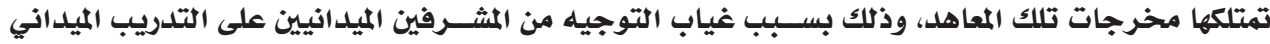

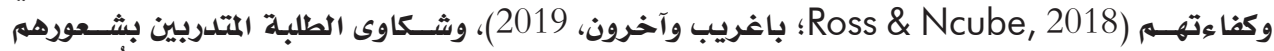

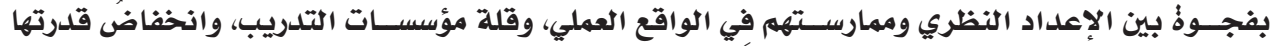

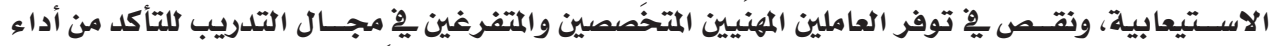

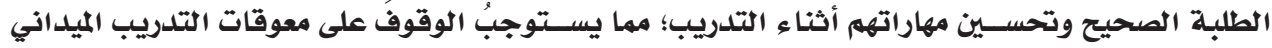

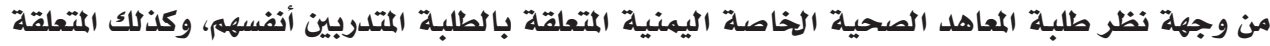

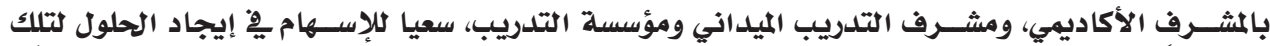

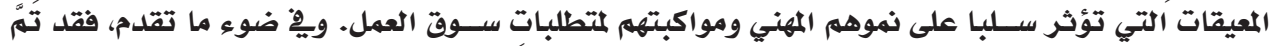

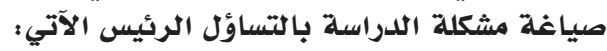

ما معوقات التدريب الميداني بالمعاهد الصحية الخاصة بالجمهورية اليمنية من وجهة نظر الطلبة؟ وينبثقُ من ذلك أسئلة فرعية أخرى يمكن صياغتها على النحو الآتي:

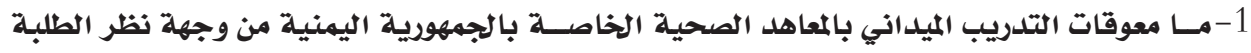
والمتعلقة بالطلبة أنفسهم: 2-مـا معوقات التلدريب الميداني بالمعاهد الصحية الخاصـــة بالجمهوريـة اليمنية من وجهة نظر الطلبة

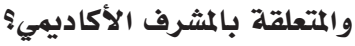
3-مــ معوقات التدريب الميداني بالمعاهد الصحية الخاصــــة بالجمهوريـة اليمنية من وجهة نظر الطلبة والمتعلقة بالمشرف الميدانيء 4-مــ معوقات التدريب الميداني بالمعاهد الصحية الخاصـــة بالجمهوريـة اليمنية من وجهة نظر الطلبة والمتعلقة بمؤسسة التدريب؟

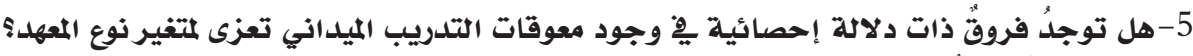

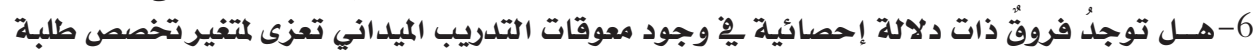

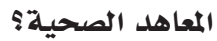


د. ماجد مهدي قاسهم القطوي

المجلد السابع والعشرون العدد (3)، سبتمبر 2021 ماجدم الفطوي ماسم

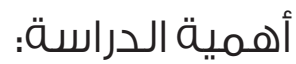

تكمنُ أهميةُ الدراسة الحالية يِّ أنها :

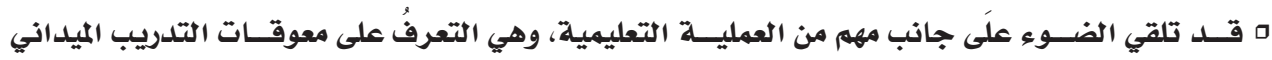

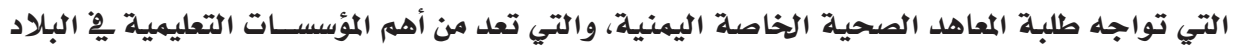

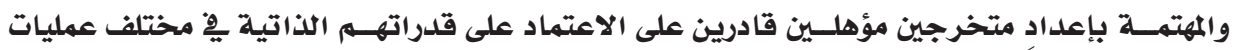

التنمية.

ه قد تسهم بِّ مساعدةٌ القائمين على التدريب الميداني لطلبة المعاهد الصحية اليمنية الخاصة كلاستفادة.

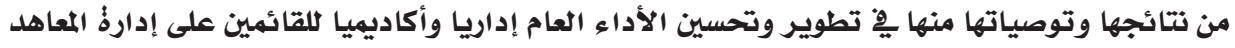
الصحية الخاصة باليمن.

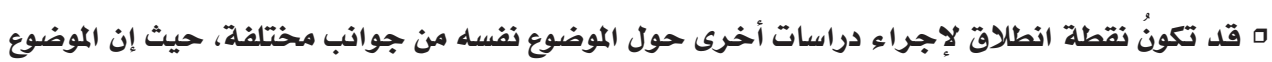

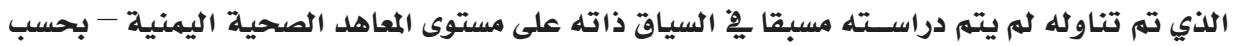

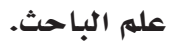
أهداف الدراسة:

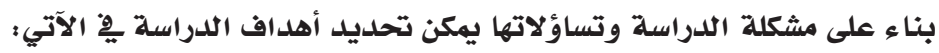

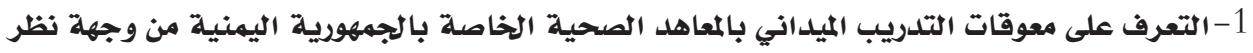

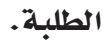
2-التعرف على معوقات التدريب الميداني بالمعاهد الصحية الخاصة بالجمهورية اليمنية من وجهة نظر الطلبة والمتعلقة بالطلبة أنفسهر. 3-التعرف على معوقات التدريب الميداني بالمعاهد الصحية الخاصة بالجمهالئهورية اليمنية من وجهة نظر الطلبة والمتعلقة بالمشرف الأكاديمي. 4- التعرف على معوقات التدريب الميداني بالمعاهد الصحية الماندية الخاصة بالجمهورية اليمنية من وجهة نظر الطلبة والمتعلقة بالمشرف الميداني.

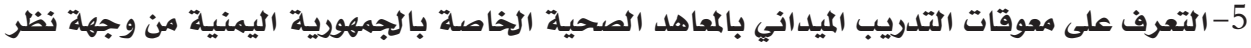
الطلبة والمتعلقة بمؤسسة التدريب. 6- التعـرف علسى وجود فروق ذات دلالة إحصائية ِِّ وجود معوقـــات التدريب الميداني تعزى لمتغيرنوع

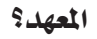
7- التعرف على وجود فروق ذات دلالة إحصائية يِّ وجود معوقات التدريب الميداني تعزى لمتغير تخصص

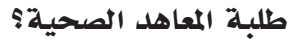

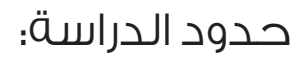

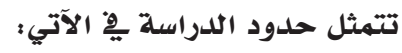

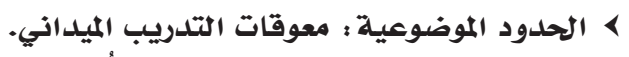

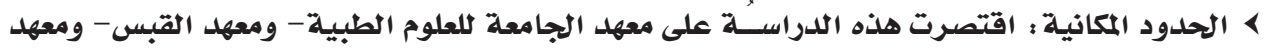

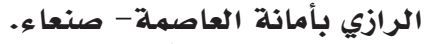

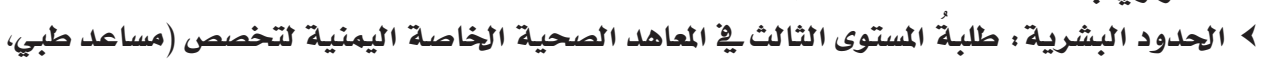

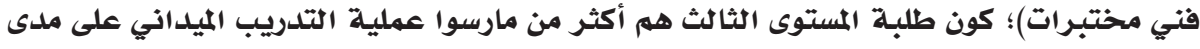

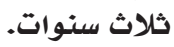
> الحدود الزمانية : الفصل الأول من العام الدراسي 2020/ 2021م. 


\section{مصطلحات الدراسة:}

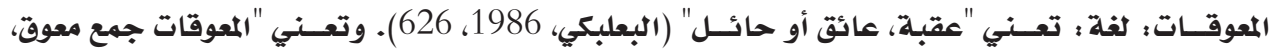

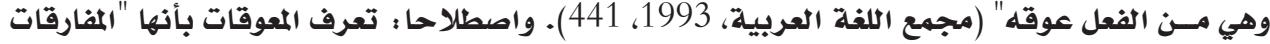

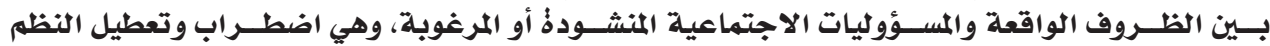

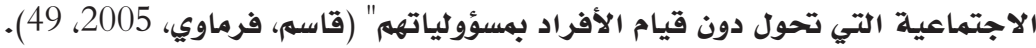

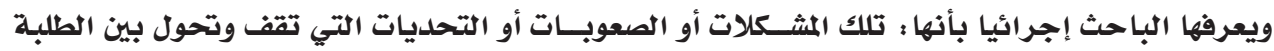

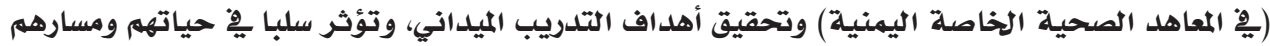
الدراسي والمهني.

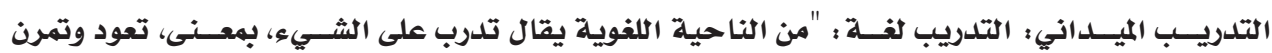

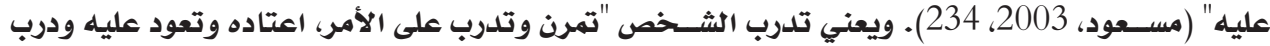

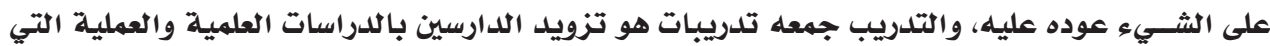

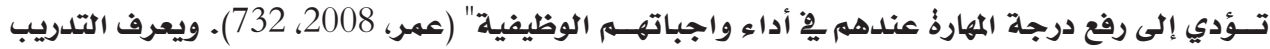

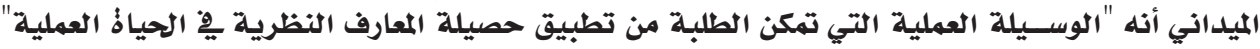

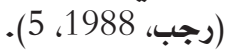

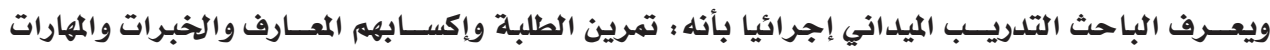

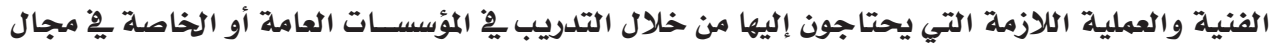

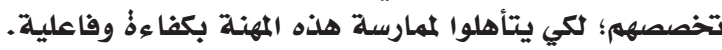

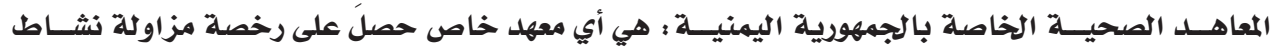

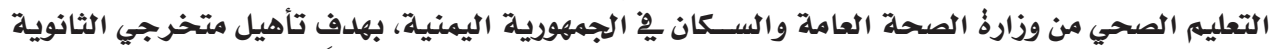

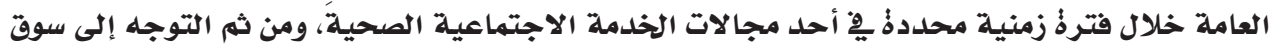

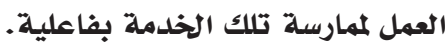
منهجية الدراسة واجـراءاتهـا: منهج الدراسة :

اعتمدت هذه الدراسة على المنهج الوصفي التحليلي؛ لأنه الأنسب لتحقيق أهدافها. مجتهع الدراسلة وعينتها :

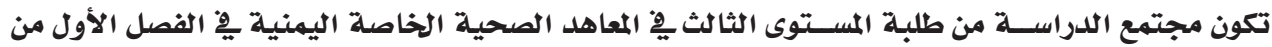

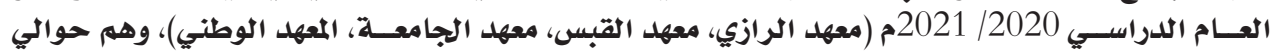

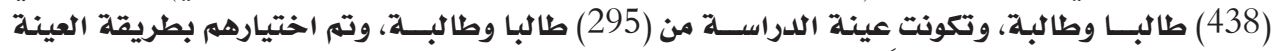

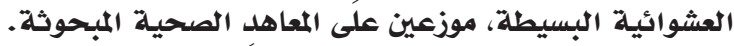
تحليل المتغيرات الديهغرافية لعينة الدراسلة ؛

تم تحليـل الخصائـص الديهغرافية للمبحوثين عينـة الدراســة، ولكل خاصية على حـــدُ، والجلدول (1) يوضح ذلك. 


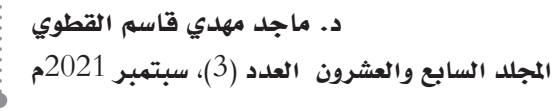

جلدول (1): التكرار والنسبة المئوية لخصائص عينة الدراسة

\begin{tabular}{|c|c|c|c|}
\hline النسبة المئوية & التكرار & الفئة & المتغير \\
\hline$\% 42.7$ & 126 & ذكر & الجنس \\
\hline$\% 57.3$ & 169 & أنثى & \\
\hline$\% 100$ & 295 & الإجمالي & \\
\hline$\% 5.4$ & 16 & أقل من 20 عاما & 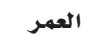 \\
\hline$\% 69.9$ & 206 & من 20 إلى أقل من 22 عاما & \\
\hline$\% 24.7$ & 73 & 22 عاما فأكثر & \\
\hline$\% 100$ & 295 & الإجمالي & \\
\hline$\% 29.5$ & 87 & معهد الجامعة & المعهد \\
\hline$\% 29.2$ & 86 & معهد القبس & \\
\hline$\% 21.7$ & 64 & معهد الرازي & \\
\hline$\% 19.7$ & 58 & المعهد الوطني العالي للعلوم الصحية & \\
\hline$\% 100$ & 295 & الإجمالي & \\
\hline$\% 73.2$ & 216 & مساعد طبي & التخصص \\
\hline$\% 26.8$ & 79 & فني مختبرات & \\
\hline$\% 100$ & 295 & الإجمالي & \\
\hline
\end{tabular}

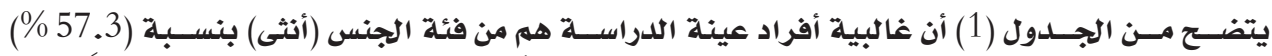

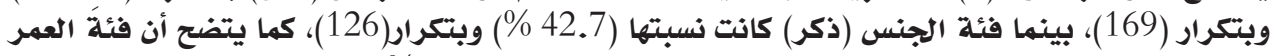

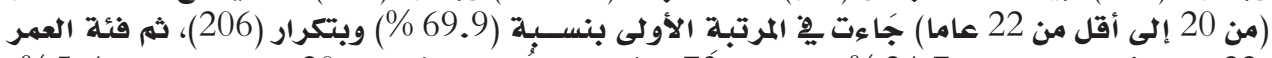

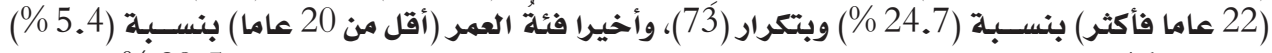

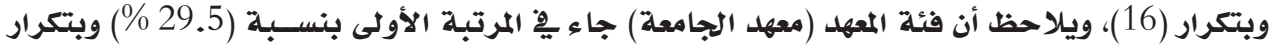

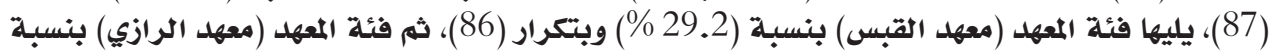

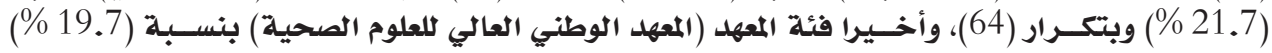

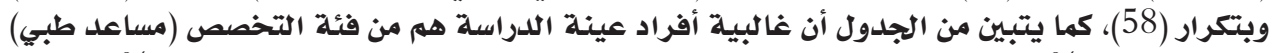

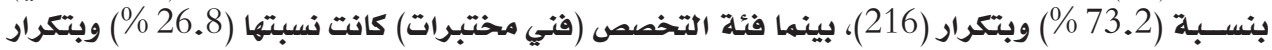

أداذٌ الدراسلة : (1)

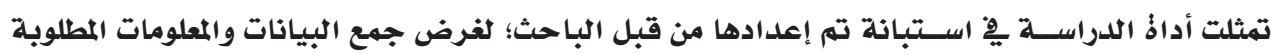

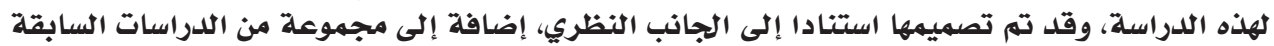

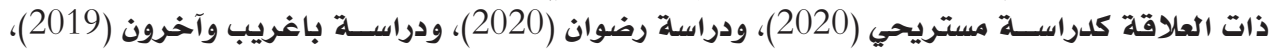

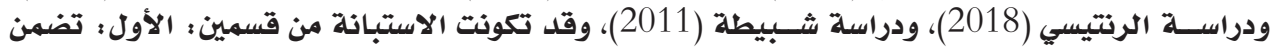

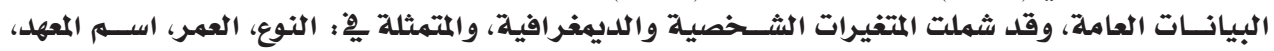

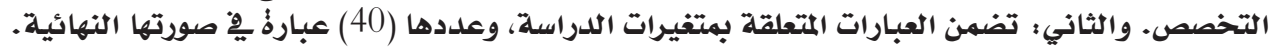

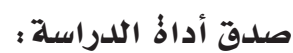

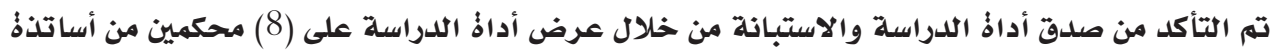

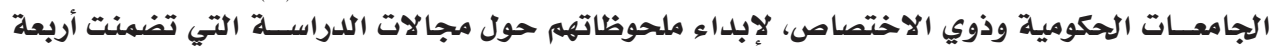

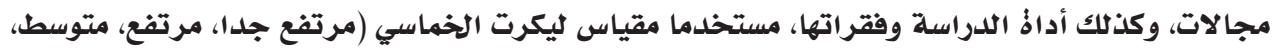

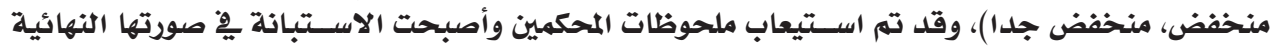

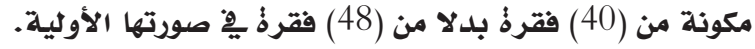


د. ماجل مهلدي قاسم القطوي

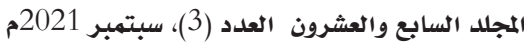

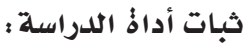

تم التأكلد من صدق ثبات أداذُ الدراســة (الاستبـانة) باستخلدام معامل كرومباخ ألفا للثبات، والجدول (2) يبين عدد العبارات ومعاملات الثبات للمجات ادلات والمات والمقياس. جدول (2) : نتيجة اختبار الثبات لعبارات المجالات

\begin{tabular}{|c|c|c|c|}
\hline معاملات كرونباخ & 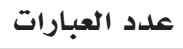 & مجالات الدراسة & r \\
\hline 0.80 & 10 & معوقات متعلقة بالطلبة المتدربين أنفسهم & 1 \\
\hline 0.91 & 10 & معوقات متعلقة بالمشرف الأكاديمي & 2 \\
\hline 0.92 & 10 & معوقات متعلقة بالمشرف الميداني & 3 \\
\hline 0.89 & 10 & معوقات متعلقة بمؤسسة التلدريب & 4 \\
\hline 0.95 & 40 & أداذٌ الدراسة ككل & \\
\hline
\end{tabular}

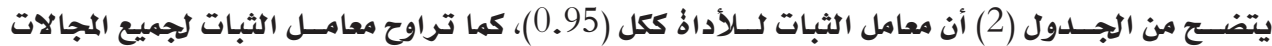

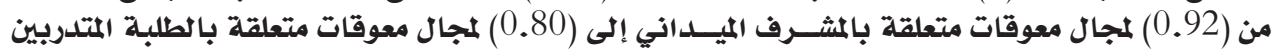

أثفسهم.

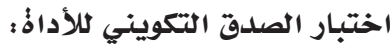

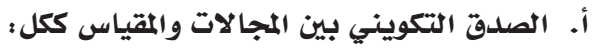

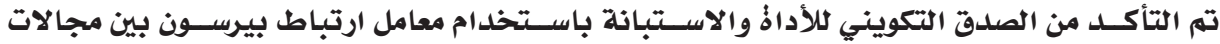

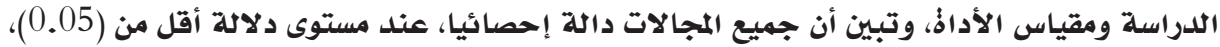
والجدول (3) يوضح ذلك.

جلدول (3): اختبار الصدق التكويني لمجالات الدراسة

\begin{tabular}{|c|c|c|c|}
\hline مستوى الدلالة & معامل الارتباط بيرسون & مجالات الدراسة & م \\
\hline .000 & $.810^{* *}$ & معوقات متعلقة بالطلبة المتدربين أنفسهم & 1 \\
\hline .000 & $.891^{* *}$ & معوقات متعلقة بالمشرف الأكاديمي & 2 \\
\hline .000 & $.885^{* *}$ & معوقات متعلقة بالمشرف الميداني & 3 \\
\hline .000 & $.788^{* *}$ & معوقات متعلقة بمؤسسة التدريب & 4 \\
\hline
\end{tabular}

ب. الصدق التكويني بين الفقرات والدرجة الكلية لكل مجال :

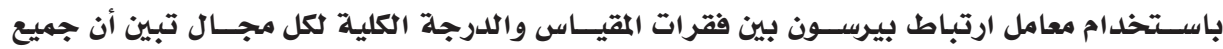

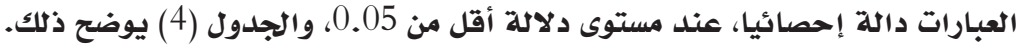

جلدول (4) : اختبار الصدق التكويني لفقرات مجال

\begin{tabular}{|c|c|c|c|c|c|}
\hline \multicolumn{3}{|c|}{ معوقات متعلقة بالمشرف الأكاديبي } & \multicolumn{3}{|c|}{ معوقات متعلقة بالطلبة المتدربين أنفسهم } \\
\hline مستوى الدلالة & معامل ارتباط بيرسون & رقم العبارةٌ & مستوى الدلالة & معامل ارتباط بيرسون & رقم العبارةٌ \\
\hline .000 & $.736^{* *}$ & B1 & .000 & $.621^{* *}$ & $\mathrm{~A} 1$ \\
\hline .000 & $.795^{* *}$ & B2 & .000 & $.598^{* *}$ & A2 \\
\hline .000 & $.760^{* *}$ & B3 & .000 & $.477^{* *}$ & A3 \\
\hline .000 & $.739^{* *}$ & B4 & .000 & $.480^{* *}$ & A4 \\
\hline .000 & $.625^{* *}$ & B5 & .000 & $.652^{* *}$ & A5 \\
\hline
\end{tabular}




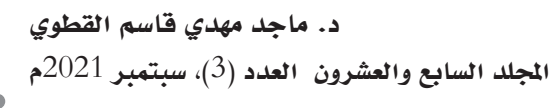

\begin{tabular}{|c|c|c|c|c|c|}
\hline \multicolumn{6}{|c|}{ جدول (4): يتبع } \\
\hline \multicolumn{3}{|c|}{ معوقات متعلقة بالمشرف الأكاديهي } & \multicolumn{3}{|c|}{ معوقات متعلقة بالطلبة المتدربين أنفسهم } \\
\hline مستوى الدلالة & معامل ارتباط بيرسون & 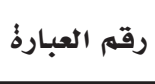 & مستوى الدلالة & معامل ارتباط بيربون & 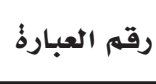 \\
\hline .000 & $.721^{* *}$ & B6 & .000 & $.599^{* *}$ & A6 \\
\hline .000 & $.805^{* *}$ & B7 & .000 & $.687^{* *}$ & A7 \\
\hline .000 & $.781^{* *}$ & B8 & .000 & $.626^{* *}$ & A8 \\
\hline .000 & $.754^{* *}$ & B9 & .000 & $.611^{* *}$ & A9 \\
\hline .000 & $.758^{* *}$ & B10 & .000 & $.615^{* *}$ & $\mathrm{~A} 10$ \\
\hline
\end{tabular}

\begin{tabular}{|c|c|c|c|c|c|}
\hline \multicolumn{3}{|c|}{ معوقات متعلقة بمؤسسة التدريب } & \multicolumn{3}{|c|}{ معوقات متعلقة بالمشرف الميداني } \\
\hline مستوى الدلالة & معامل ارتباط بيرسون & رقم العبارةٌ & مستوى الدلالة & معامل ارتباط بيرسون & رقم العبارة: \\
\hline .000 & $.697^{* *}$ & D1 & .000 & $.768^{* *}$ & C1 \\
\hline .000 & $.672^{* *}$ & D2 & .000 & $.767^{* *}$ & $\mathrm{C} 2$ \\
\hline .000 & $.715^{* *}$ & D3 & .000 & $.772^{* *}$ & $\mathrm{C} 3$ \\
\hline .000 & $.678^{* *}$ & D4 & .000 & $.808^{* *}$ & $\mathrm{C} 4$ \\
\hline .000 & $.717^{* *}$ & D5 & .000 & $.785^{* *}$ & C5 \\
\hline .000 & $.715^{* *}$ & D6 & .000 & $.783^{* *}$ & C6 \\
\hline .000 & $.726^{* *}$ & D7 & .000 & $.708^{* *}$ & C7 \\
\hline .000 & $.775^{* *}$ & D8 & .000 & $.823^{* *}$ & $\mathrm{C} 8$ \\
\hline .000 & $.681^{* *}$ & D9 & .000 & $.615^{* *}$ & C9 \\
\hline .000 & $.717^{* *}$ & D10 & .000 & $.741^{* *}$ & $\mathrm{C} 10$ \\
\hline \multicolumn{6}{|c|}{${ }^{* *}$ Correlation is significant at the 0.01 level (2-tailed). } \\
\hline
\end{tabular}

المعالجات الإحصائية المستخلدمة يِّ الدراسلة :

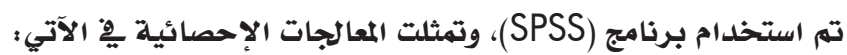

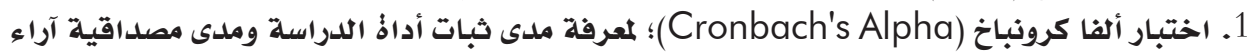

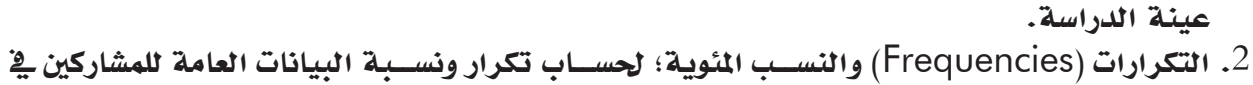
عينة الدراسة.

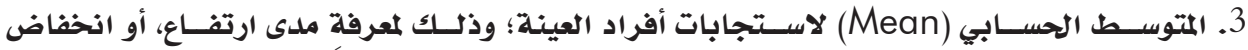

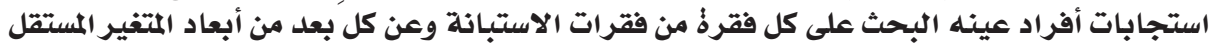

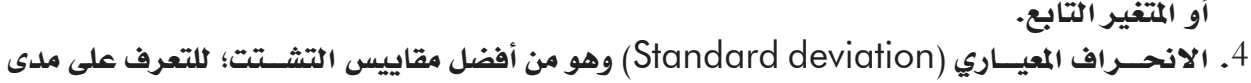

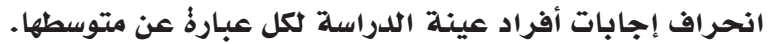

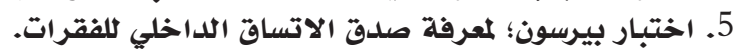

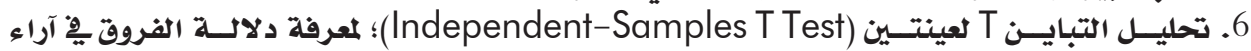

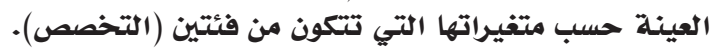

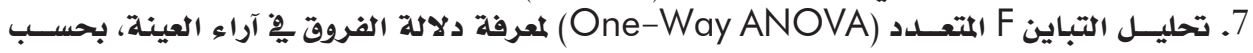
متغيراتها الشخصية التياين التي تتكون من ثلاث فئات فأكثر (المعهد).

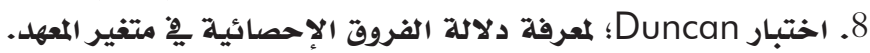




\section{نتائج الدراسة ومناقشتها:}

لقد تم احتساب التقدير اللفظي لمحاور الدراسة وفقا للجدول (5). جلدول (5) : كيفية احتساب التقدير اللفظي لأسئلة الدراسة الدولة

\begin{tabular}{|c|c|c|}
\hline \multicolumn{3}{|c|}{ كيفية احتساب التقدير اللفظي } \\
\hline إذا كانت النسبـة & التقدير اللفظي & إذا كان المتوسط \\
\hline أقل من 36 \% & منخفض جلا & أقل من 1.8 \\
\hline من 36 \% وأقل من 52 \% & منخفض & من 1.8 وأقل من 2.6 \\
\hline من 52 \% وأقل من 68 \% & 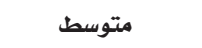 & من 2.6 وأقل من 3.4 \\
\hline من 68 \% وأقل من 84 \% & 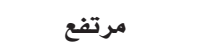 & من 3.4 وأقل من 4.2 \\
\hline من 84 \% حتى 100 \% & مرتفع جدا & من 4.2 حتى 5 \\
\hline
\end{tabular}

وفيما يلي عرضٌ لنتائج الدراسة ومناقشتها، وفقا لتسلسل تساؤلات الدراسلة ؛

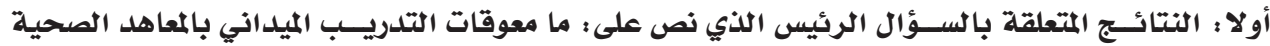

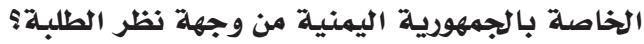

لإجابة عن السؤال الرئيس تَّم حساب المتوسط الحسابي والانحراف المعياري والنسبة المئوية لكل مجال

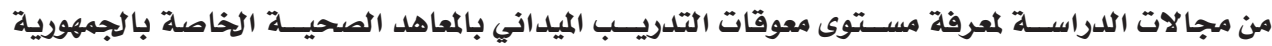

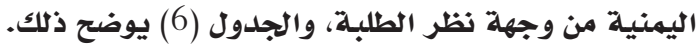

$$
\text { جدول (6) : المتوسطات والانحرافات لمجالات معوقات التدريب الميداني دولي }
$$

\begin{tabular}{|c|c|c|c|c|c|}
\hline التقلدير & النسبي & الانحياري & الحستوسطي & المجالات & م \\
\hline مرتفع & $\% 69.2$ & .801 & 3.46 & المعوقات المتعلقة بالطلبة المتدربين أنفسهه & 1 \\
\hline 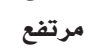 & $\% 75.2$ & 1.024 & 3.76 & المعوقات المتعلقة بالمشرف الأكاديمي & 2 \\
\hline 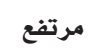 & $\% 76.2$ & 1.008 & 3.81 & المعوقات المتعلقة بالمشرف الميداني & 3 \\
\hline 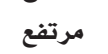 & $\% 76.2$ & .917 & 3.81 & المعوقات المتعلقة بمؤسسة التدريب & 4 \\
\hline 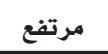 & $\% 74.2$ & .794 & 3.71 & متوسط معوقات التدريب الميداني & \\
\hline
\end{tabular}

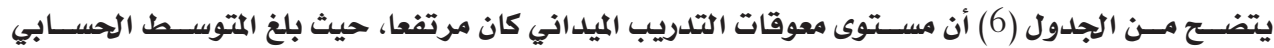

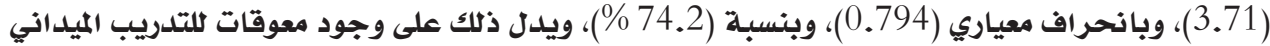

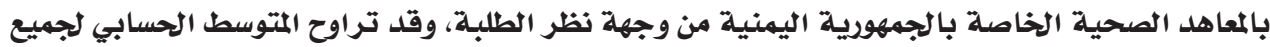

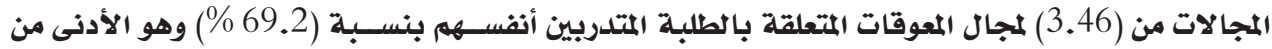

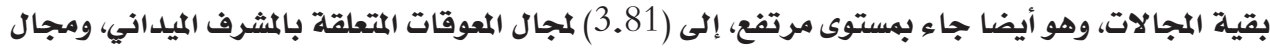

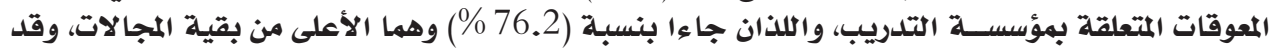

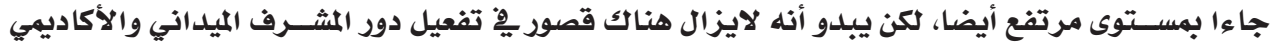

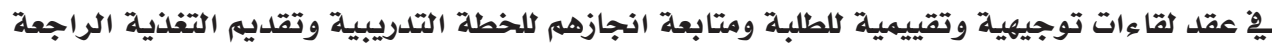

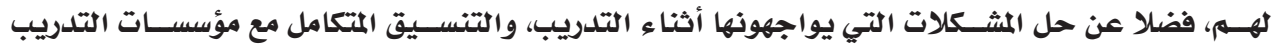

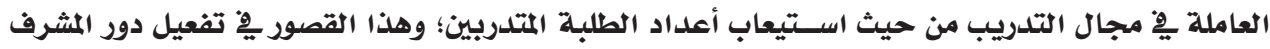

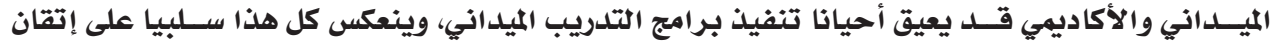

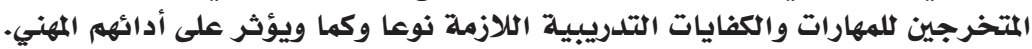

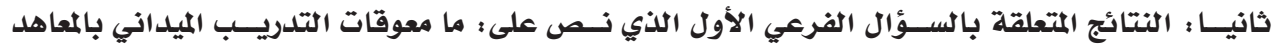

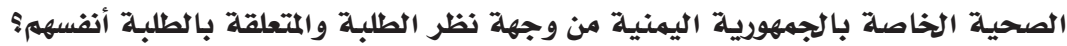


د. ماجد مهدي قاسم القطوي

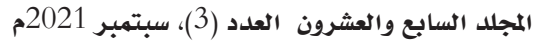

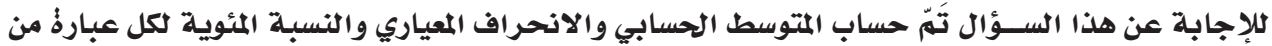

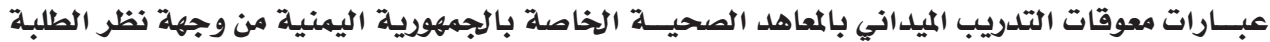

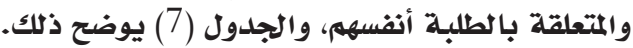
جدول (7) : المتوسطات الحسابية والانحرافات المعيارية والنسبة لجال المعوقات المتعلقة بالطلبة المتدربين أنفسهم

\begin{tabular}{|c|c|c|c|c|c|}
\hline التقلدير & النوزن النسبي & الانحراف & المتوسطابي & 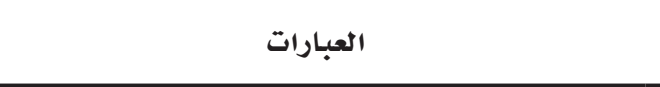 & م \\
\hline مرتفع & $\% 82.4$ & 1.196 & 4.12 & شعرت خلال فترةٌ التدريب الميداني بالملل نظرا لغياب عنصر & 1 \\
\hline 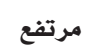 & $\% 78.6$ & 1.278 & 3.93 & منزلي بعيد عن مكان مؤسسات التدريب الميداني. & 2 \\
\hline 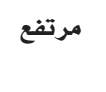 & $\% 74.4$ & 1.306 & 3.72 & واجهت صعوبة يْ كتابة التقارير المطلوبة مني أثناء التدريب & 3 \\
\hline 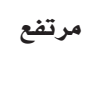 & $\% 73.6$ & 1.262 & 3.68 & لدي قصور يِّ الربط بين الجانب النظري والجانب العملي خلال التدريب الميداني. & 4 \\
\hline مرتفع & $\% 72.6$ & 1.323 & 3.63 & لم أطلع على خطة وموضوعات التدريب قبل التحاقي بالتدريب & 5 \\
\hline مرتفع & $\% 70.8$ & 1.447 & 3.54 & 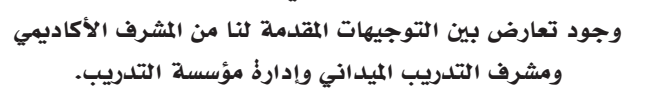 & 6 \\
\hline متوسط & $\% 64.2$ & 1.484 & 3.21 & غيابي المتكرر يفقدني خبرات عملية كثيرة ِِِ التدريب الميداني. & 7 \\
\hline متوسط & $\% 62.8$ & 1.380 & 3.14 & أشعر بقصور ِِّ معرفة وفهم أنظمة ولوائح مؤسسة التدريب. & 8 \\
\hline متوسط & $\% 58.2$ & 1.406 & 2.91 & أشعر بضعف التعاون بيني وبين زملائي يِّ أداء المهام التدريبية. & 9 \\
\hline 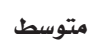 & $\% 54.0$ & 1.412 & 2.70 & ضعف التزامي ببرنامج التدريب الميداني والساعات المحددةٌ له. & 10 \\
\hline 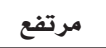 & $\% 69.2$ & .801 & 3.46 & متوسط المعوقات المتعلقة بالطلبة المتدربين أنفسهم & \\
\hline
\end{tabular}

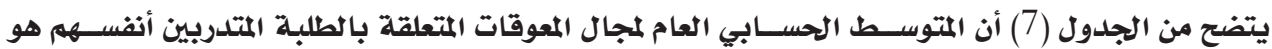

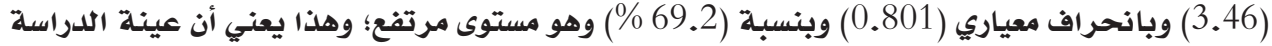

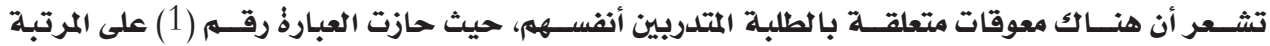

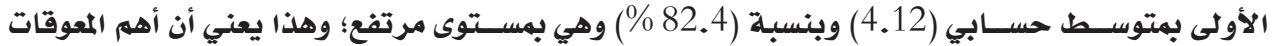

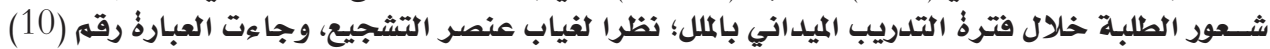

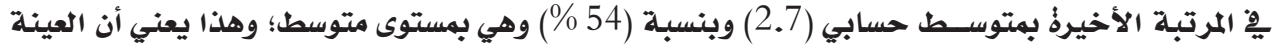

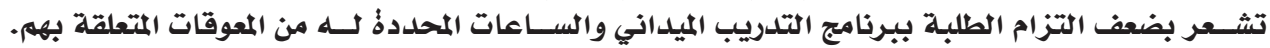

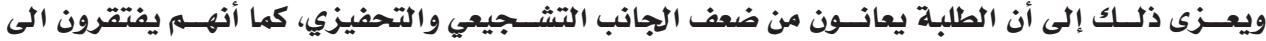

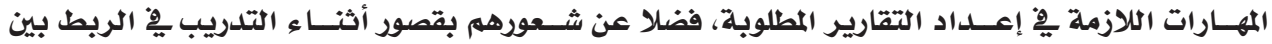

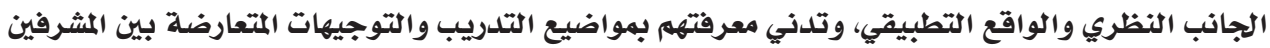

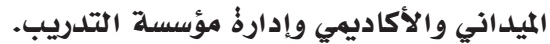

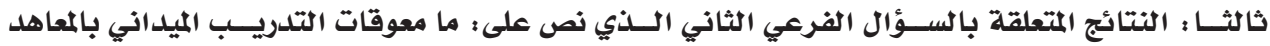
الصحية الخاصة بالجمهورية اليهنية من وجهة نظر الطلبة والمتعلقة بالمشرف الأكاديميء

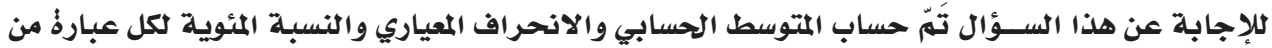

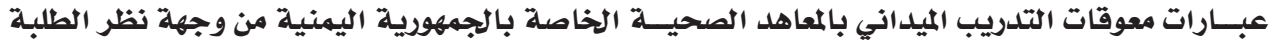

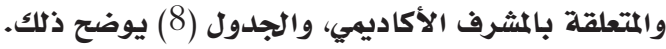


جدول (8) : المتوسطات الحسابية والانحرافات المعيارية والنسبة لمجال المعوقات المتعلقة بالمشرف الأكاديمي

\begin{tabular}{|c|c|c|c|c|c|}
\hline التقلدير & 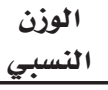 & الانحراف & المتوسطابي & العبارات & م \\
\hline مرتفع & $\% 79.4$ & 1.312 & 3.97 & 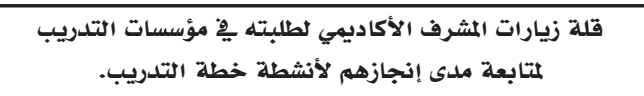 & 1 \\
\hline مرتفع & $\% 77.0$ & 1.366 & 3.85 & لم يقم المشرف الأكاديمي بتعريف الطلبة ببرنامج وموضوعات التلديب التدريب. & 2 \\
\hline مرتفع & $\% 76.8$ & 1.345 & 3.84 & لا يقدم المشرف الأكاديمي التغذية الراجعة والتطويرية للطلبة & 3 \\
\hline مرتفع & $\% 76.4$ & 1.394 & 3.82 & قلة سعي المشرف الأكاديمي إلى معرفة مشكلات الطلبة المتدربين & 4 \\
\hline مرتفع & $\% 76.2$ & 1.379 & 3.81 & 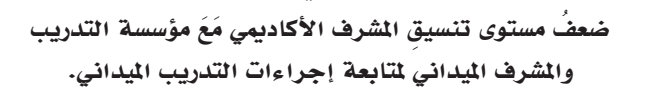 & 5 \\
\hline مرتفع & $\% 76.0$ & 1.353 & 3.80 & 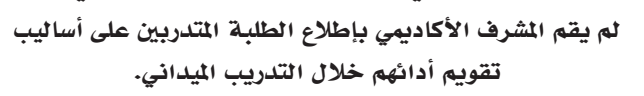 & 6 \\
\hline مرتفع & $\% 74.6$ & 1.388 & 3.73 & 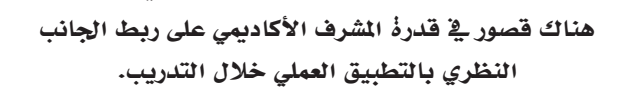 & 7 \\
\hline مرتفع & $\% 74.2$ & 1.356 & 3.71 & كثرةٌ عدد الطلبة الذين يشرف عليهم المشرف الأكاديمي يوِ & 8 \\
\hline مرتفع & $\% 71.8$ & 1.389 & 3.59 & ضعف معارف ومهارات المشرف الأكاديمي وقدراته بِّ الجانب & 9 \\
\hline مرتفع & $\% 69.2$ & 1.406 & 3.46 & يشعر المشرف الأكاديمي أن الحافز والعائد من متابعته للتدريب & 10 \\
\hline مرتفع & $\% 75.2$ & 1.024 & 3.76 & متوسط المعوقات المتعلقة بالمشرف الأكادييي & \\
\hline
\end{tabular}

يتضحُ من الجلدول (8) أن المتوسـَط الحسـابي العام لمجال المعوقات المتعلقة بالمشرف الأكاديهي هو (3.76)

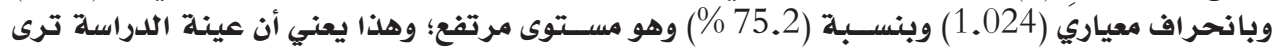

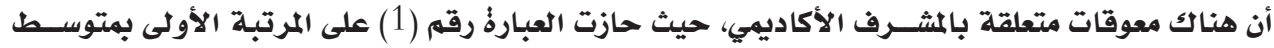

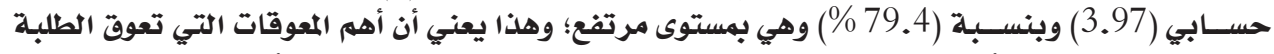

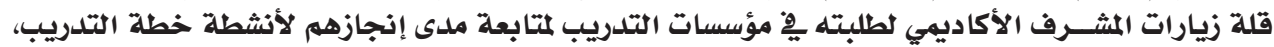

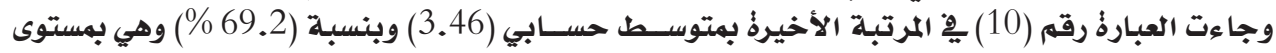

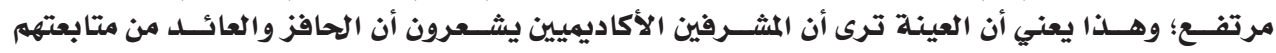

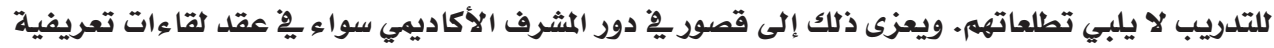

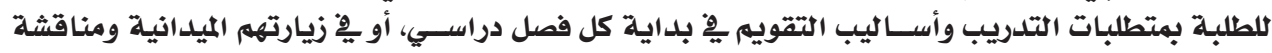

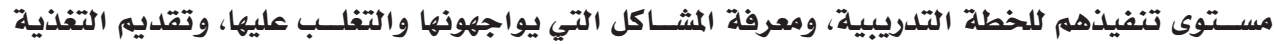

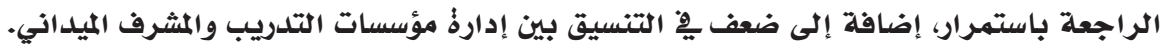

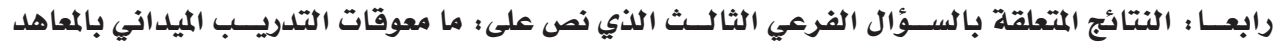

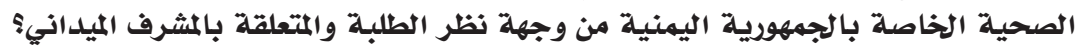

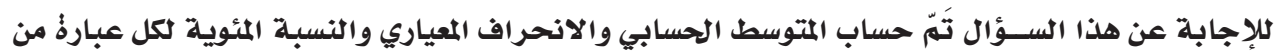

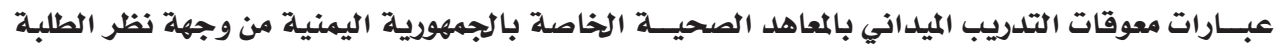

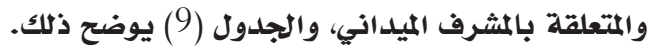


د. ماجد مهدي قاسم القطوي

المجلد السابع والعشرون العدد (3)، سبتمبر 2021م فاسم الفطوي

جدول (9): المتوسطات الحسابية والانحرافات المعيارية والنسبة لمجال المعوقات المتعلقة بالمشرف الميداني

\begin{tabular}{|c|c|c|c|c|c|}
\hline التقلدير & 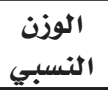 & الانحراف & المتوسطابي & العبـارات & م \\
\hline مرتفع & $\% 80.8$ & 1.273 & 4.04 & إهمال المشرف الميداني عقد اجتماعات دورية مع الطلبة لمناقشة & 1 \\
\hline 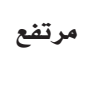 & $\% 80.0$ & 1.266 & 4.00 & لا يقوم المشرف الميداني بتوضيح المهام المطلوبة من كل طالب & 2 \\
\hline مرتفع & $\% 79.0$ & 1.377 & 3.95 & 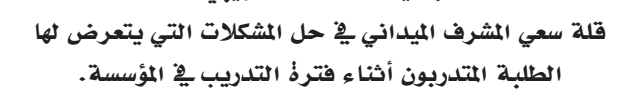 & 3 \\
\hline 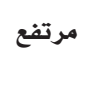 & $\% 77.6$ & 1.302 & 3.88 & 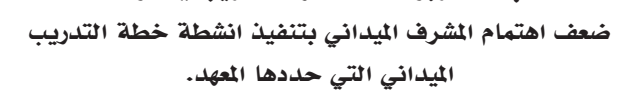 & 4 \\
\hline مرتفع & $\% 76.0$ & 1.315 & 3.80 & ضعف الدافع والحافز لدى المشرف الميداني يفٍ الإشراف على الملى & 5 \\
\hline 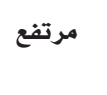 & $\% 75.4$ & 1.349 & 3.77 & تهاون المشرف الميداني بمتابعة مستوى التزام الطلبة بحضور & 6 \\
\hline مرتفع & $\% 75.2$ & 1.332 & 3.76 & 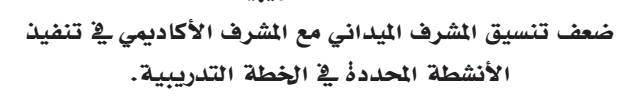 & 7 \\
\hline مرتفع & $\% 74.6$ & 1.340 & 3.73 & كثرة الأعباء المهنية للمشرف الميداني داخل مؤسسة التدريب & 8 \\
\hline مرتفع & $\% 74.0$ & 1.353 & 3.70 & ضعف قدرات ومهارات المشرف الميداني ِِّ تنفيذ مهامه & 9 \\
\hline مرتفع & $\% 69.4$ & 1.414 & 3.47 & يميز المشرف الميداني يِّ تعامله وأساليب تقييمه بين الطلبة & 10 \\
\hline 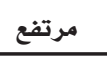 & $\% 76.2$ & 1.008 & 3.81 & متوسط المعوقات المتعلقة بالمشرف الميداني & \\
\hline
\end{tabular}

يتضحُ من الجدول (9) أن المتوســط الحســابي العام لمجال المعوقات المتعلقة بالمشــرف الميداني هو (3.81)

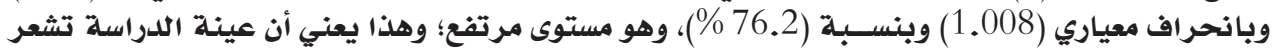

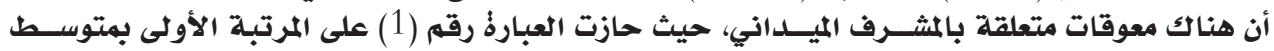

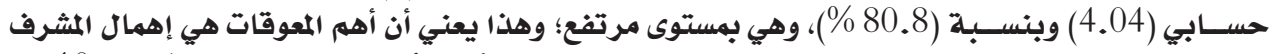

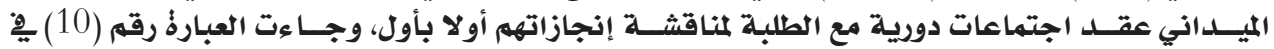

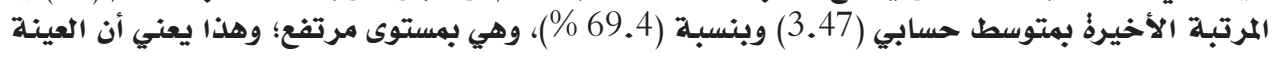

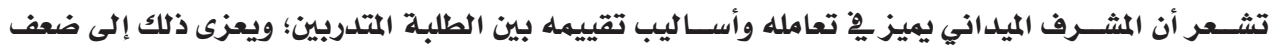

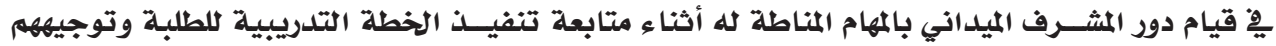

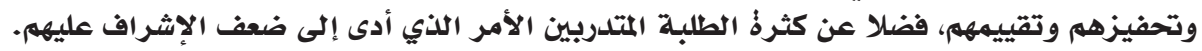

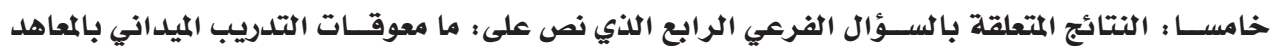

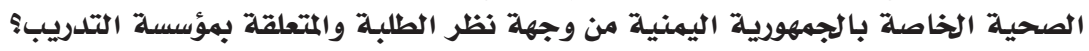

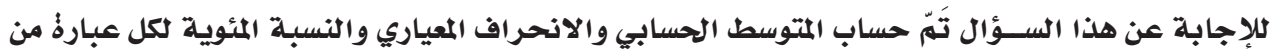

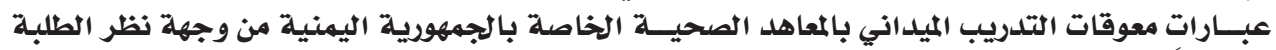

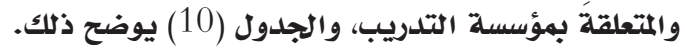


جلدول (10) : المتوسطات الحسابية والانحرافات المعيارية والنسبة لمجال المعوقات المتعلقة بمؤسسة التدريب

\begin{tabular}{|c|c|c|c|c|c|}
\hline التقدير & النوزن النسبي & الانحراف & المتوسط الجسي & العبارات & $\hat{~}$ \\
\hline مرتفع & $\% 83.0$ & 1.167 & 4.15 & 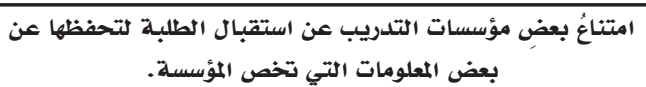 & 1 \\
\hline 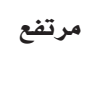 & $\% 80.0$ & 1.304 & 4.00 & لا تتيح مؤسسة التدريب الفرصَ الكافيةً للطلبة المتدربين & 2 \\
\hline 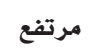 & $\% 79.4$ & 1.217 & 3.97 & تعلُّ مؤسسات التدريب أن الطلبة المتدربين يشكلون عبئًا عليها. & 3 \\
\hline 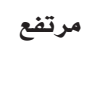 & $\% 79.2$ & 1.160 & 3.96 & قصور قيام مؤسسة التدريب بتذليل المعوقات التي تواجه طلبـ التدريب ألميداني أولاول. & 4 \\
\hline 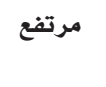 & $\% 77.6$ & 1.283 & 3.88 & قلة عدد مؤسسات التدريب العاملة ِِّ مجال التدريب الميداني & 5 \\
\hline مرتفع & $\% 75.6$ & 1.325 & 3.78 & 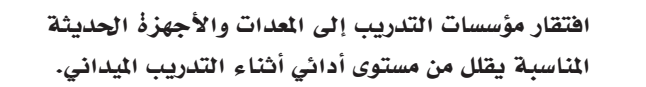 & 6 \\
\hline 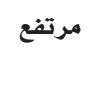 & $\% 74.6$ & 1.320 & 3.73 & 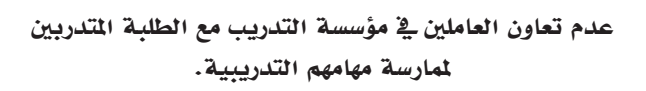 & 7 \\
\hline 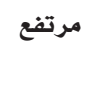 & $\% 72.6$ & 1.331 & 3.63 & 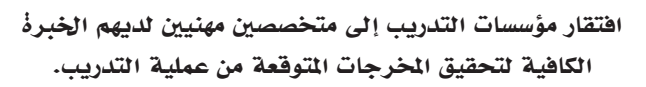 & 8 \\
\hline 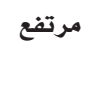 & $\% 71.0$ & 1.432 & 3.55 & تكلف إدارةٌ مؤسسة التدريب الطلبة المتدربين بمهام لا تتعلق & 9 \\
\hline 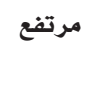 & $\% 69.2$ & 1.409 & 3.46 & 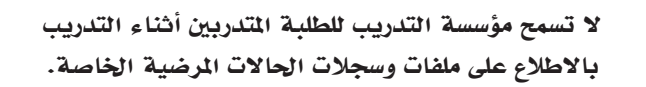 & 10 \\
\hline مرتفع - مرت & $\% 76.2$ & .917 & 3.81 & متوسط المعوقات المتعلقة بمؤسسة التدريب & \\
\hline
\end{tabular}

يتضحُ من الجلدول (10) أن المتوســط الحســابي العام لمجال المعوقات المتعلقة بمؤسسة التدريب هو (3.81)

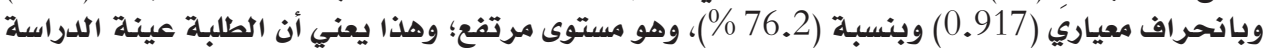

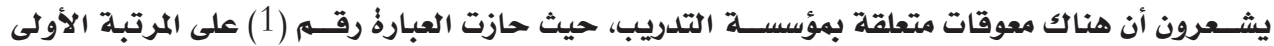

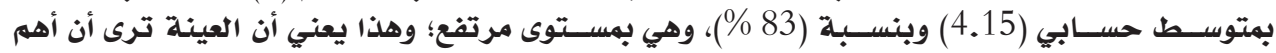

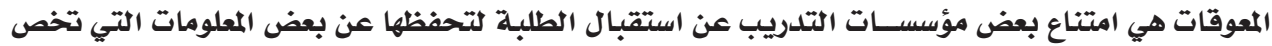

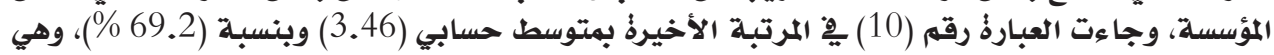

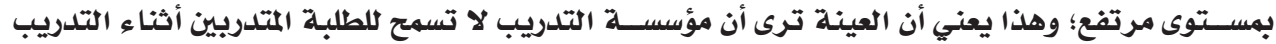

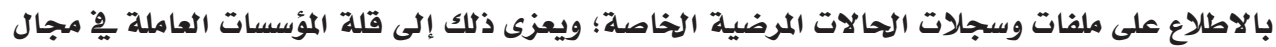

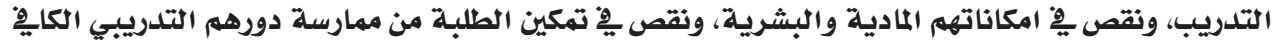

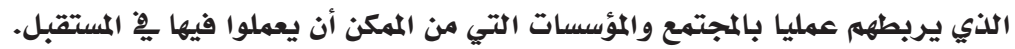

سادسـا : النتائج المتعلقة بالسؤال الفرعي الخامس الذي نص على : هل توجئ توجد فروق ذات دلالة إحصائية

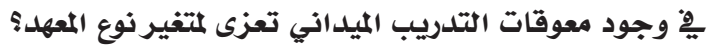

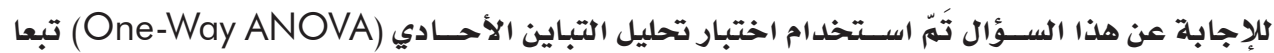

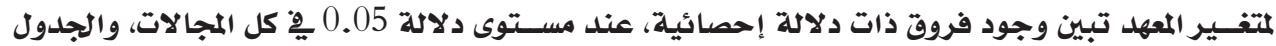
(11) يوضح ذلك. 
د. ماجد مهلي قاسب القطوي

المجلد السابع والعشرون العلدد (3)، سبتمبر 2021م

جلدول (11): اختبار تحليل التباين الأحادي (One-Way ANOVA) لمعرفة دلالة الفروق بِّ آراء العينة حسب نوع المعهد

\begin{tabular}{|c|c|c|c|c|c|c|}
\hline مستوى الدلالة & قيمة F F & متوسط المربعات & الحرجية & مجربعات & مصدر التباين & المحور أو المجال \\
\hline \multirow[t]{3}{*}{.000} & 33.114 & 16.022 & 3 & 48.066 & بين المجموعات & المعوقات المتعلقة بالطلبة \\
\hline & & .484 & 291 & 140.796 & داخل المجموعات & المتدربين أنفسه \\
\hline & & & 294 & 188.862 & المجموع الكلي & \\
\hline \multirow[t]{3}{*}{.000} & 32.373 & 25.737 & 3 & 77.210 & بين المجموعات & المعوقات المتعلقة بالمشرف \\
\hline & & .795 & 291 & 231.347 & داخل المجموعات & الأكاديمي \\
\hline & & & 294 & 308.557 & المجموع الكلي & \\
\hline \multirow[t]{3}{*}{.000} & 48.063 & 32.962 & 3 & 98.885 & بين المجموعات & المعوقات المتعلقة بالمشرف \\
\hline & & .686 & 291 & 199.568 & داخل المجموعات & الميداني \\
\hline & & & 294 & 298.453 & المجموع الكلي & \\
\hline \multirow[t]{3}{*}{.000} & 20.358 & 14.305 & 3 & 42.915 & بين المجموعات & المعوقات المتعلقة \\
\hline & & .703 & 291 & 204.478 & داخل المجموعات & بمؤسسة التدريب \\
\hline & & & 294 & 247.393 & المجموع الكلي & \\
\hline \multirow[t]{3}{*}{.000} & 51.010 & 21.302 & 3 & 63.907 & بين المجموعات & مقياس معوقات التدريب \\
\hline & & .418 & 291 & 121.524 & داخل المجموعات & الميداني \\
\hline & & & 294 & 185.431 & المجموع الكلي & \\
\hline
\end{tabular}

يتضــح من الجدول (11) أن قيمة F جاءت دالة يِّ كل المجــالات، وهذا يعني وجود فروق جوهرية وذات

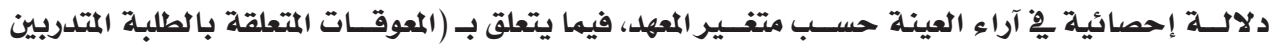

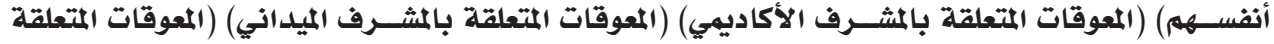
بهؤسسة التدريب) (مقياس معوقات التدريب الميداني).

ولمعرفة الفروق يِّ متغير المعهد قام الباحث باسـتخدام اختبـار Duncan لإيجاد هذه الفروق، والجلدول (12) يوضح ذلك.

جدول (12): اختبار Duncan (1,2,3) المدى المتعدد حسب متغير المعهد للمجالات ذات الدلالة الإحصائية

\begin{tabular}{|c|c|c|c|c|c|}
\hline \multicolumn{3}{|c|}{ Subset for alpha $=.05$} & \multirow{2}{*}{$\mathrm{N}$} & \multirow{2}{*}{ المعهد } & \multirow{2}{*}{ المجال } \\
\hline 3 & 2 & 1 & & & \\
\hline & & 2.71 & 87 & معهد الرازي & المعوقات المتعلقة بالطلبة \\
\hline & 3.55 & & 86 & معهد القبس & المتدربين أنفسهه \\
\hline & 3.70 & & 64 & المعهد الوطني العالي للعلوم الصحية & \\
\hline & 3.76 & & 58 & معهد الجامعة & \\
\hline & .093 & 1.000 & & Sig. & \\
\hline & & 2.90 & 87 & معهد الرازي & المعوقات المتعلقة بالمشرف \\
\hline & 3.64 & & 86 & معهد القبس & 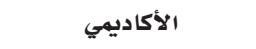 \\
\hline 4.20 & & & 64 & معهد الجامعة & \\
\hline 4.22 & & & 58 & المعهد الوطني العالي للعلوم الصحية & \\
\hline .869 & 1.000 & 1.000 & & Sig. & \\
\hline
\end{tabular}


جدول (12): يتبع

\begin{tabular}{|c|c|c|c|c|c|}
\hline \multicolumn{3}{|c|}{ Subset for alpha $=.05$} & \multirow{2}{*}{$\mathrm{N}$} & \multirow{2}{*}{ 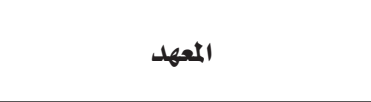 } & \multirow{2}{*}{ 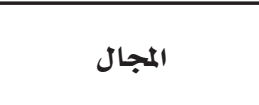 } \\
\hline 3 & 2 & 1 & & & \\
\hline & & 2.80 & 87 & معهد الرازي & المعوقات المتعلقة بالمشرف \\
\hline & 3.76 & & 86 & معهد القبس & 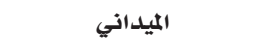 \\
\hline 4.28 & & & 64 & 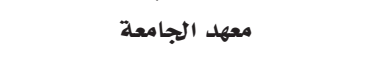 & \\
\hline 4.30 & & & 58 & المعهد الوطني العالي للعلوم الصحية & \\
\hline \multirow[t]{8}{*}{.872} & 1.000 & 1.000 & & Sig. & \\
\hline & & 3.11 & 87 & معهد الرازي & المعوقات المتعلقة بمؤسسة \\
\hline & 3.87 & & 86 & معهد القبس & 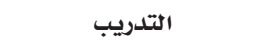 \\
\hline & 4.06 & & 64 & معهد الجامعة & \\
\hline & 4.13 & & 58 & المعهد الوطني العالي للعلوم الصحية & \\
\hline & .077 & 1.000 & & Sig. & \\
\hline & & 2.88 & 87 & معهد الرازي & مقياس معوقات التدريب \\
\hline & 3.70 & & 86 & معهد القبس & الميداني الميد \\
\hline 4.07 & & & 64 & معهد الجامعة & \\
\hline 4.09 & & & 58 & المعهد الوطني العالي للعلوم الصحية & \\
\hline .893 & 1.000 & 1.000 & & Sig. & \\
\hline
\end{tabular}

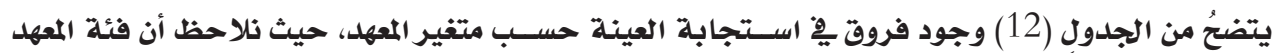

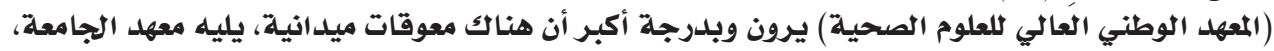

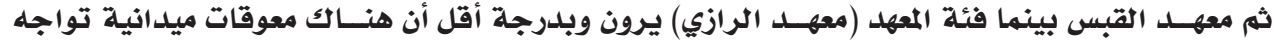

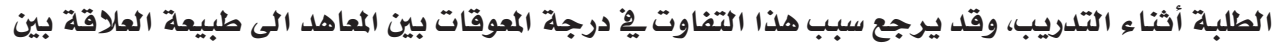

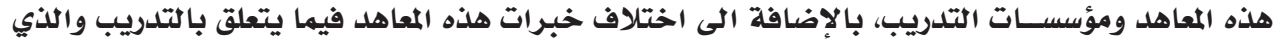
نتج عنـه خبرات ومعوقات ميدانية مختلفة بحسب وجهة نظر التهر العينة.

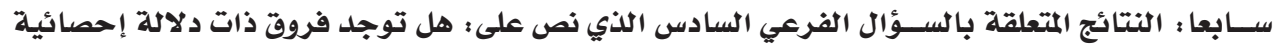

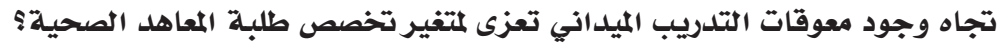

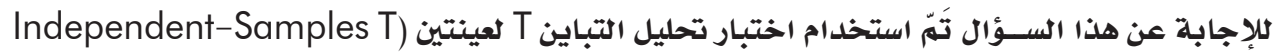

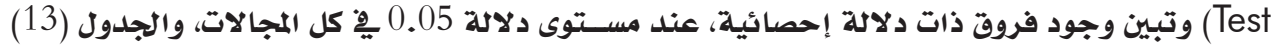
يوضح ذلك. جدول (13): نتيجة اختبار (T-test) لدلالة الفروق بين متوسطات آراء أفراد العينة وفقا لمتغير التخصص

\begin{tabular}{|c|c|c|c|c|c|c|c|}
\hline اللفظية & مستوى الدلاكة & قيمة & الانحرياري & المتوسطابي & العدد العد & التخصص & المجالات \\
\hline \multirow[t]{2}{*}{ دالة } & .012 & 2.527 & .825 & 3.52 & 216 & مساعد طبي & المعوقات المتعلقة بالطلبة \\
\hline & & & .707 & 3.28 & 79 & فني مختبرات & المتدربين أنفسهـ \\
\hline \multirow[t]{2}{*}{ دالة } & .000 & 4.648 & 1.051 & 3.90 & 216 & مساعد طبي & المعوقات المتعلقة بالمشرف \\
\hline & & & .829 & 3.36 & 79 & فني مختبرات & الأكاديمي \\
\hline \multirow[t]{2}{*}{ دالة } & .000 & 5.055 & 1.026 & 3.97 & 216 & مساعد طبي & المعوقات المتعلقة بالمشرف \\
\hline & & & .818 & 3.38 & 79 & فني مختبرات & الميداني \\
\hline
\end{tabular}


جدول (13):يتبع

\begin{tabular}{|c|c|c|c|c|c|c|c|}
\hline اللفظية الدلة & مستوى الدلالة & قيمة & الانحمياري & المتوسطابي & العلدد & التخصص & المجالات \\
\hline \multirow[t]{2}{*}{ دالة } & .001 & 3.255 & .949 & 3.91 & 216 & مساعد طبي & المعوقات المتعلقة بمؤسسة \\
\hline & & & .772 & 3.55 & 79 & فني مختبرات & التدريب \\
\hline \multirow[t]{2}{*}{ دالة } & .000 & 4.778 & .816 & 3.83 & 216 & مساعد طبي & مقياس معوقات التدريب \\
\hline & & & .635 & 3.39 & 79 & فني مختبرات & الميداني \\
\hline
\end{tabular}

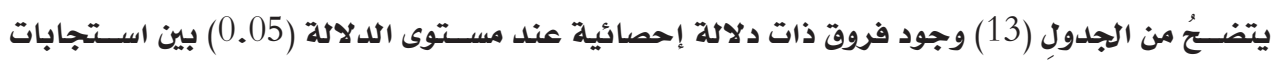

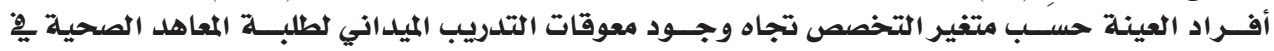

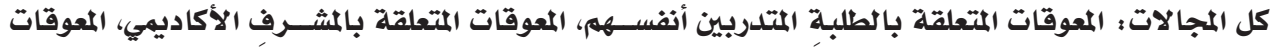

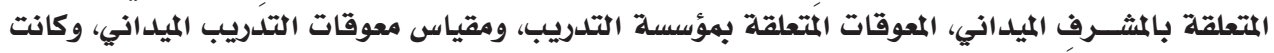

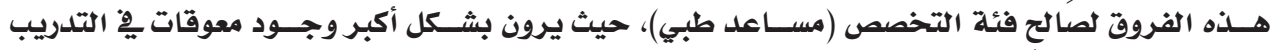

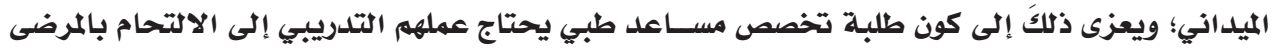

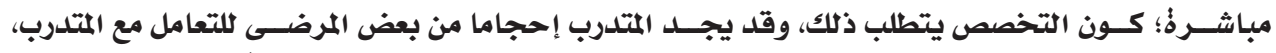

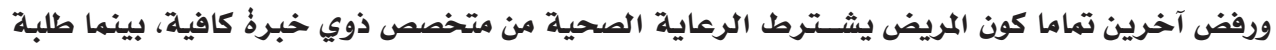

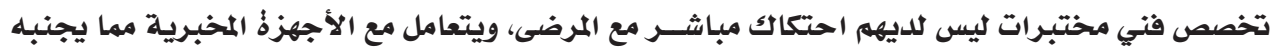

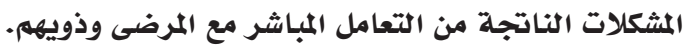

وتتفق نتائج هذه الدراسة مع ما توصلت إليه دراسة مستريحي (2020)، ودراسة رضوان (2020) (2020)، ودراسة

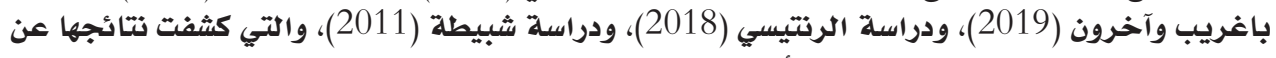

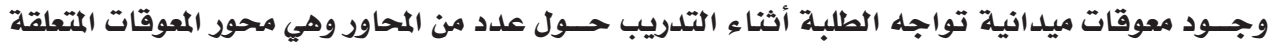

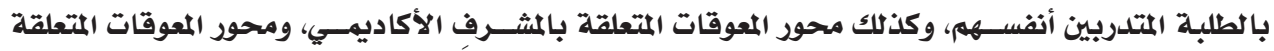

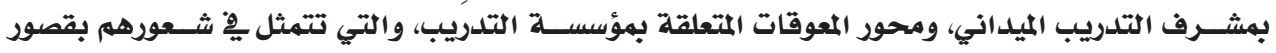

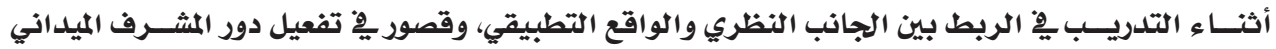

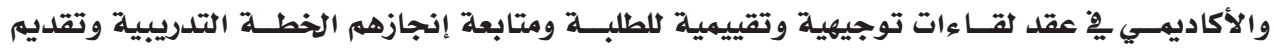

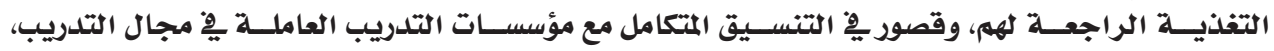

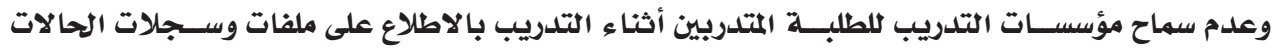

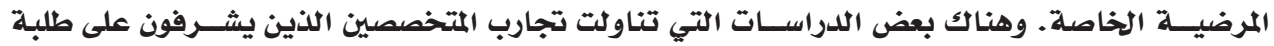

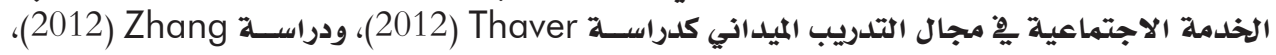

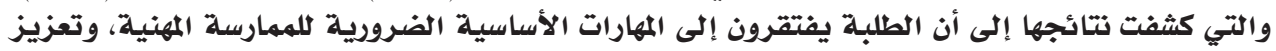

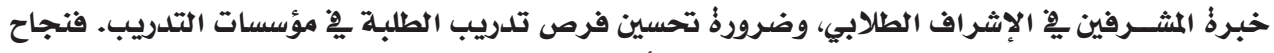

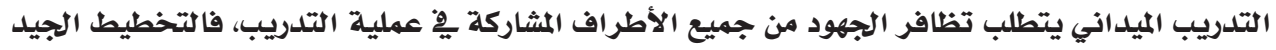

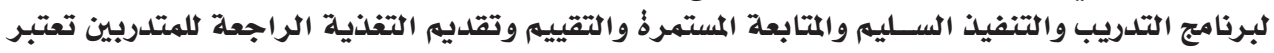

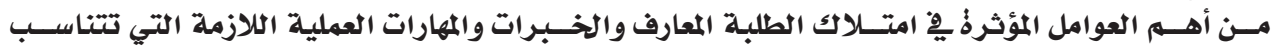

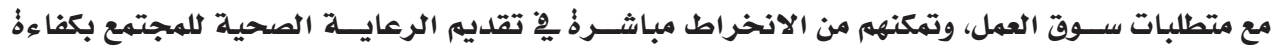
وفاعلية واقتدار.

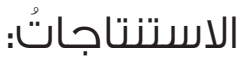

فِي ضَوءِ النتائج التي توصلت إليها الدراسة، تَّمّ تقديم الاستنتاجات الآتية ؛

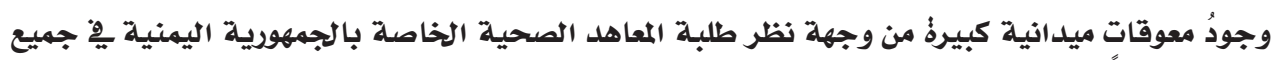

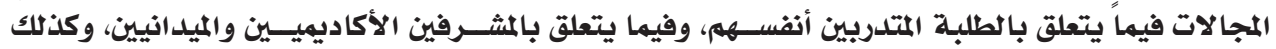


مِّْو ضوء الاستنتاجات التي توصلت إليها الدراسة، يمكنُ تقديُُ التوصيات الآتية :

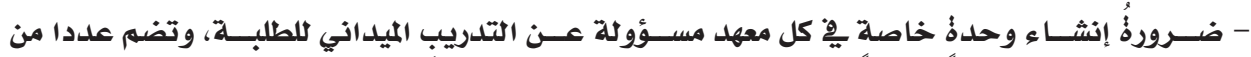

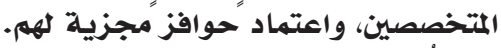

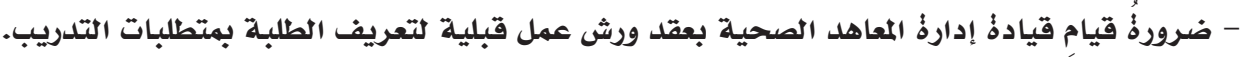

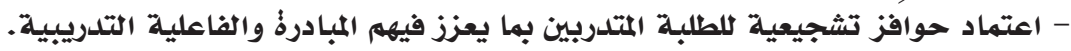

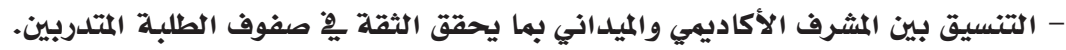

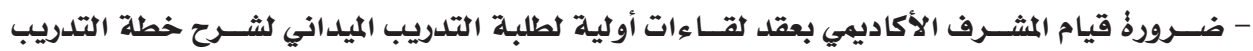

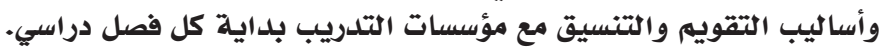

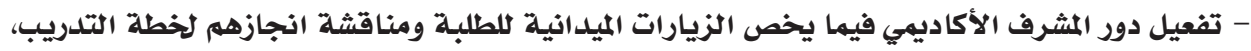

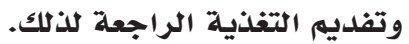

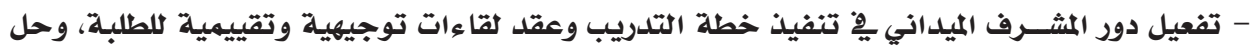

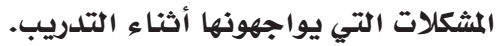

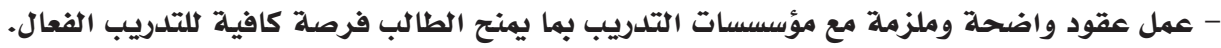

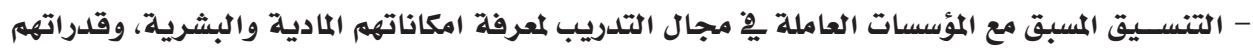

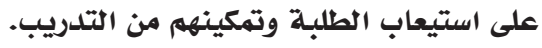

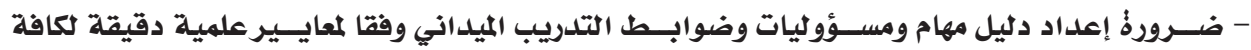

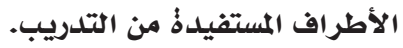

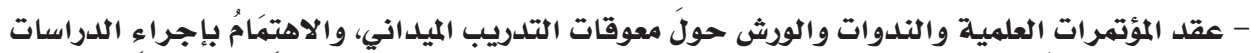
والبحوث حَوْل ذلك. المقترحاتُ: أمراث

- إجراء دراســة مماثلة حول معوقات التدريب الميلداني من وجهة نظر طلبـة الجامعات وكليات المجتمع الحكومية والأهلية.

- إجراءُ دراسة حولَّ معوقات التدريب الميداني من وجهة نظر إدارةٌ المعاهد الصحية اليهنية الخاصة.

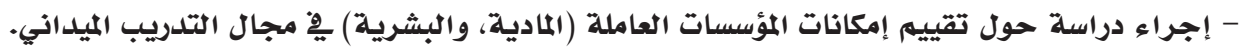

المـراجع: أنمراء

أبـو النصر، مدحت (2008)، إدارةٌ العهليــة التلدريبية : النظرية والتطبيـق (ط1)، القاهرذٌ ؛ دار الفجر

$$
\text { للنشر والتوزيع. }
$$

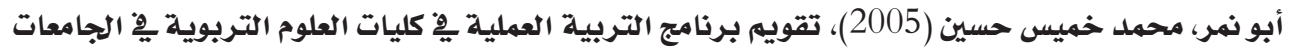

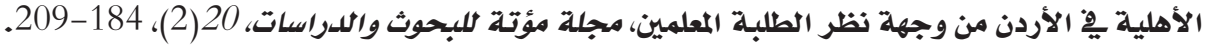

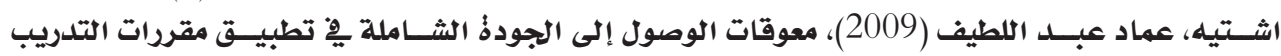

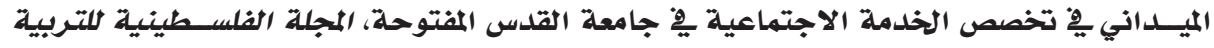

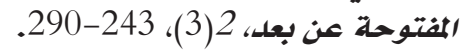

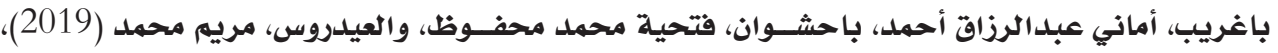

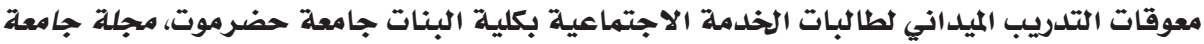

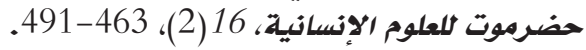
البعلبكي، منير (1986)، قاموس المورد، بيروت : دار العله للملايين. 
د. ماجد مهدي قاسم القطوي

المجلد السابع والعشرون العدد (3)، سبتمبر 2021 ماجديم المطوي

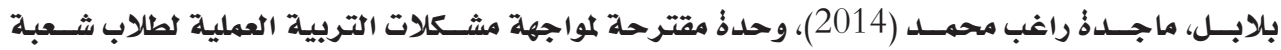

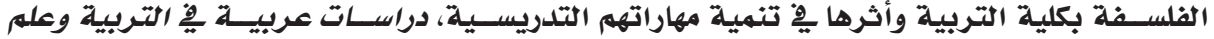

$$
\text { النفس، (52)، 101-144. }
$$

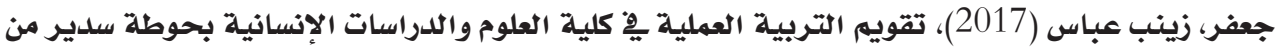

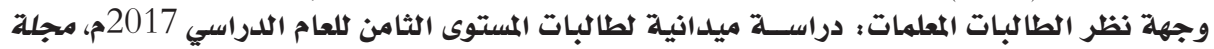

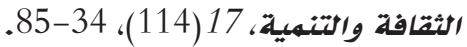

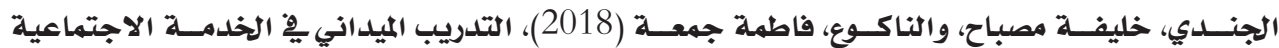

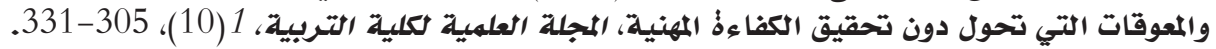

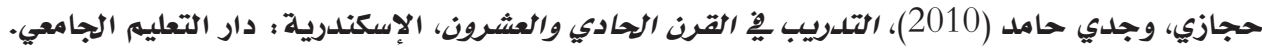

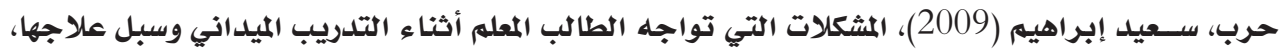

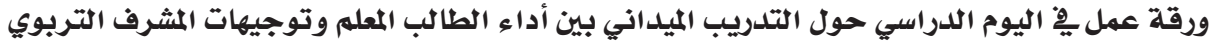

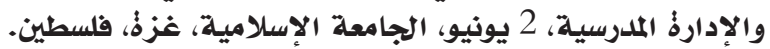

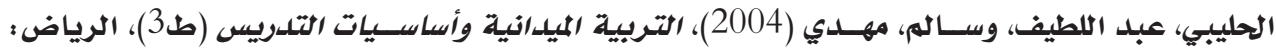
مكتبة العبيكان. حنفي، عبد الغفار (1993)، السلوك التنظيهي وإدارةٌ الأضراد، الإسكندرية : المكتب العربي الحديث.

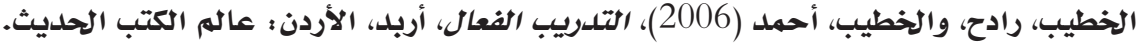

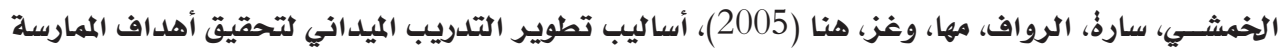

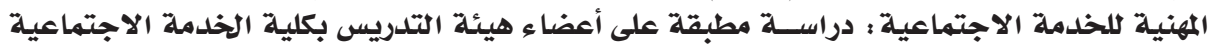

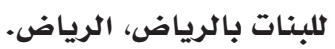

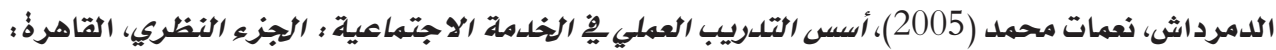

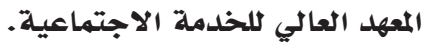

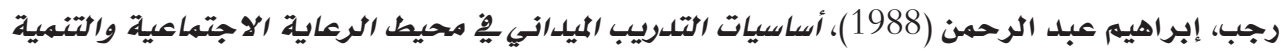

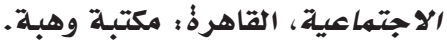

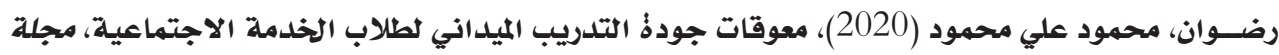

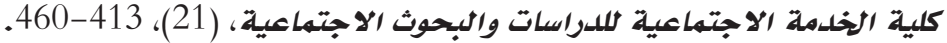

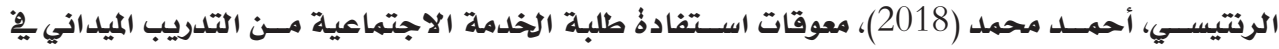

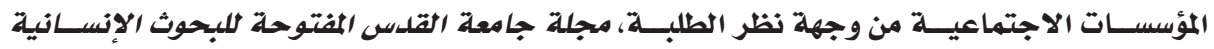

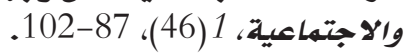

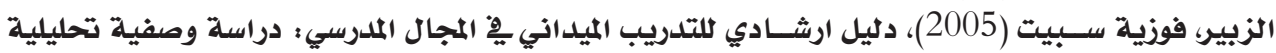

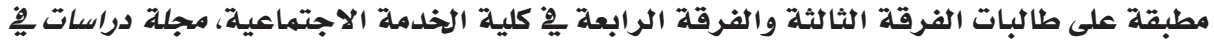

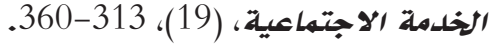
سـعل، محمود حسـان (2000)، التربية العهلية بين النظرية والتطبيـق (طمة (1)، عمان، الأردن : دار الفكر للطباعة والنشر.

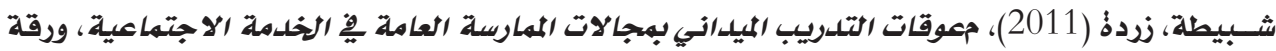

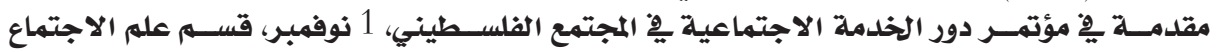

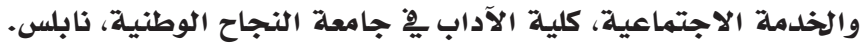

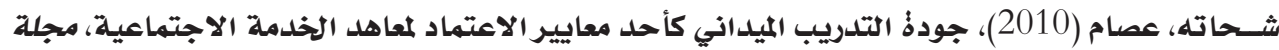
دراسات في الخلدمة الاجتهاعية والعلوم الإنسانية، (10)، 1294، 1291-1321. 


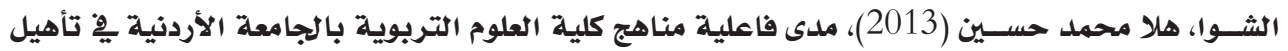

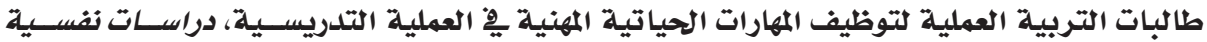

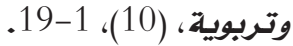

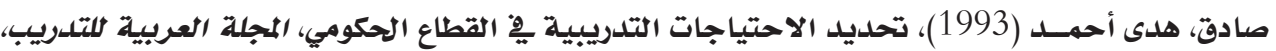
. 5

الطعاني، حسن أحمد (2007)، التلدريب الإداري المعاصر، عمان ؛ دار المسيرةٌ للنشر.

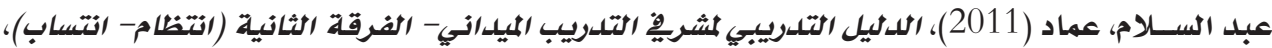
مصر : جامعة الفيوم.

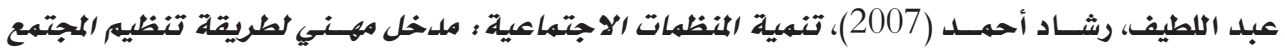

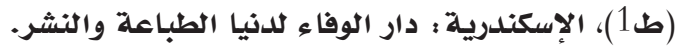

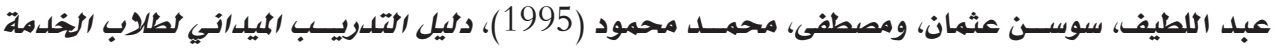

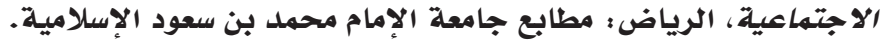

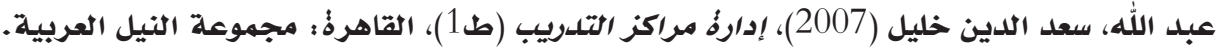

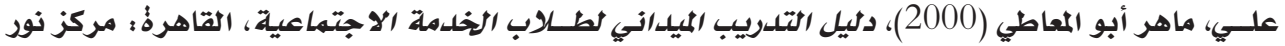
الالايمان.

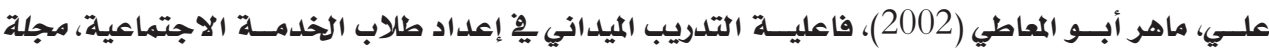

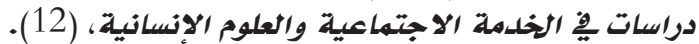

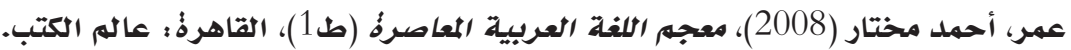

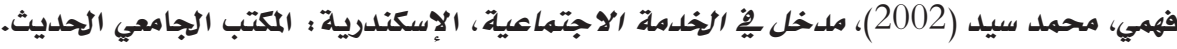

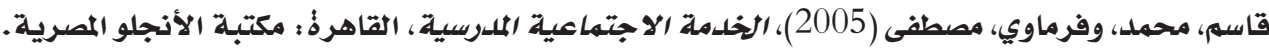

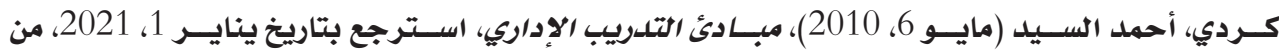
http://kenanaonline.com/users/ahmedkordy/posts/123730

اللوزي، بسـمة (1982)، أسـاليب التعرف على الوحتياجات التلدريبية، القاهــرةٌ : المنظمة العربية للعلوم الإدارية.

مجمع اللغة العربية (1993)، المعجه الوجيز، القاهرةٌ : الهيئة العامة لشؤون المطابع الأميرية.

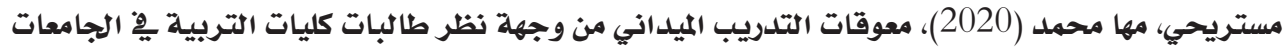

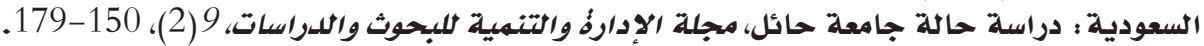

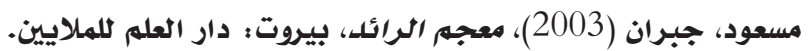

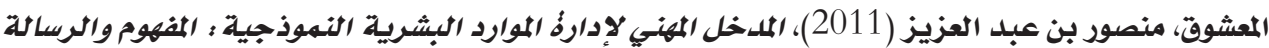

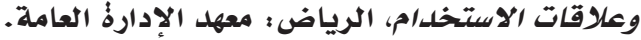

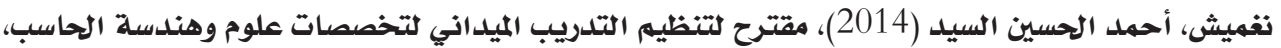

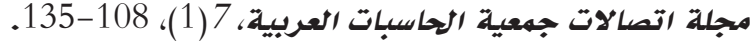

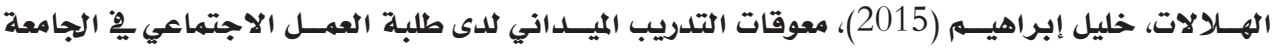

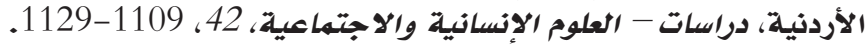

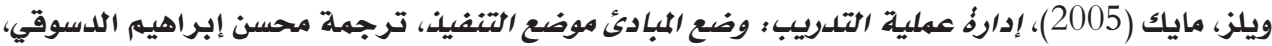

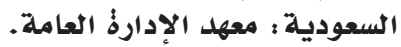

ياغي، محمد عبد الفتاح (2011)، مبادئ الإدارةٌ العامة (ط2)، عمان : دار وائل للطباعة والنشر. 


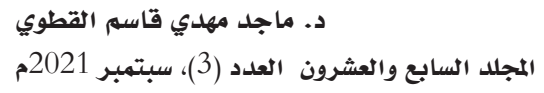

Jinks, M. (1979). Training. London: Blandford Press.

John, P. (2008). Training Research and Practice (3 ${ }^{\text {rd }}$ ed.). London: Academic Press.

Ross, E., \& Ncube, M. (2018). Student social workers' experiences of supervision. Social Sciences, 79(1), 31-54.

Tam, C. O., \& Lo Fu, Y. W. (2001). The changing roles of practicum/field experience tutors. Paper presented at the Symposium on Field Experience, The Hong Kong Institute of Education, China.

Thaver, W. (2012). The experiences of social workers as supervisors of social work students field placements (Master thesis). University of KwaZulu-Natal, Durban, South Africa.

Zhang, H. (2012). Development of a supervision model of social work practicum in Mainland China with Jinan Shandong as an example (Doctoral dissertation). Hong Kong Polytechnic University, Hong Kong.

\section{Arabic References in Roman Scripts:}

Abdellatif, Rashad Ahmed (2007), Tanmiat almunazamat alaijtimaeiati: Madkhal mihniun litariqat tanzim almujtamae (Taba'a 1), Al'iiskandiriat: Dar Alwafa' Lidunya Altibaeat Walnashri.

Abdellatif, Sawsan Othman, and Mustafa, Muhammad Mahmoud (1995), Dalil altadrib almaydanii litulaab alkhidmat alaijtimaeiati, Alriyad: Mutabie Jamieat Al'iimam Muhammad Ibn Saud Al'iislamiati.

Abdullah, Saad Eddin Khalil (2007), Idarat marakiz altadrib (Taba'a 1), Alqahirati: Majmueat Alniyl Alearabiati.

Abdulsalam, Emad (2011), Aldalil altadribiu limashrifi altadrib almaydani Alfirqat althaania (Aintizami - aintisabi), Misr: Jamieat Alfium.

Abu Al-Nasr, Medhat (2008), Idarat aleamaliat altadribiati: alnazariat waltatbia (Taba'a 1), Alqahirata: Dar Alfajr Lilnashr Waltawziei.

Abu Nimer, Muhammed Khamis Hussein (2005), Taqwim barnamaj altarbiat aleamaliat fi kuliyaat aleulum altarbawiat fi aljamieat al'ahliat fi Al'urduni min wijhat nazar altalabat almuealimina, Majalat Mutat Lilbuhuth Waldirasati, 20(2), 184-209.

Al-Baalbaki, Mounir (1986), Qamus almurdi, Bayrut: Dar Aleilm Lilmalayini.

Al-Damardash, Naeamat Muhamad (2005), Usus altadrib aleamalii fi alkhidmat alaijtimaeiati: Aljuz' alnazaria, Alqahirati: Almaehad Aleali Lilkhidmat Alaijtimaeiati.

Al-Halibi, Abdul Latif, wa Salem, Mahdi (2004), Altarbiat almaydaniatwa'asasiaat altadris (Tab'a' 3), Alrayad: Maktabat Aleabikan. 


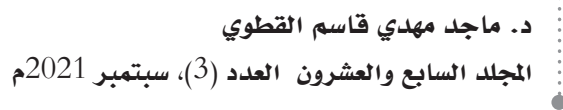

Alhilalat, Khalil Ibrahim (2015), Mueawiqat altadrib almaydanii ladaa talabat aleamal alaijtimaeii fi aljamieat Al'urduniyati, Dirasat - Aleulum Al'iinsaniat Walaijtimaeiati, 42, 1109-1129.

Ali, Maher Abu Al-Maati (2000), Dalil altadrib almaydanii litulaab alkhidmat alaijtimaeiati, Alqahirat: Markaz Nur Alayman.

Ali, Maher Abu Al-Maati (2002), Faeiliat altadrib almaydanii fi 'iiedad tulaab alkhidmat alaijtimaeiati, Majalat Dirasat fi Alkhidmat Alaijtimaeiat Waleulum Al'iinsaniati, (12).

Al-Jundi, Khalifa Misbah, wa Al-Nakou', Fatima Juma'a (2018), Altadrib almaydaniu fi alkhidmat alaijtimaeiat walmueawiqat alati tahul dun tahqia alkafa'at almihniati, Almajalat Aleilmiat Likuliyat Altarbiati, 1(10), 305-331.

Al-Khatib, Radeh, wa Al-Khatib, Ahmed (2006), Altadrib alfaeali, Irbid, Al'urdunu: Ealim Alkutub Alhadithi.

Al-Khimshi, Sarat, Alrawafi, Maha, wa Ghazi, Hana (2005), Asalib tatwir altadrib almaydanii litahqia 'ahdaf almumarasat almihniat lilkhidmat alaijtimaeiati: Dirasatan mutbaqatan ealaa 'aeda' hayyat altadris bikuliyat alkhidmat alaijtimaeiat lilbanat bialriyad, Alriyad.

Alluwzi, Basma (1982), Asalib altaearuf ealaa aliahtiajat altadribiati, Alqahirati: Almunazamat Alearabiat Lileulum Al'iidariati.

Al-Ma'shouq, Mansour bin Abdulaziz (2011), Almadkhal almihniu li'iidarat almawarid albashariat alnamudhaiiati: Almafhum walrisalat waealaqat alaistikhdami, Alriyad: Maehad Al'iidarat Aleamati.

Al-Rantisi, Ahmed Muhammad (2018), Mueawiqat aistifadat talabat alkhidmat alaijtimaeiat min altadrib almaydanii fi almuasasat alaijtimaeiat min wijhat nazar altalabati, Majalat Jamieat Alquds Almaftuhat Lilbuhuth Al'iinsaniat Walaijtimaeiati, 7(46), 87-102.

Al-Shawwa, Hala Muhammad Hussein (2013), Madaa faeiliat manahii Kuliyat Aleulum Altarbawiat bi Aljamieat Al'urduniyat fi tahil talibat altarbiat aleamaliat litawzif almaharat alhayatiat almihniat fi aleamaliat altadrisiati, Dirasat Nafsiat Watarbawiat, (10), 1-19.

Al-Taani, Hassan Ahmed (2007), Altadrib al'iidariu almueasiru, Amman: Dar Almasirat Lilnashri.

Al-Zubayr, Fawzia Sabeit (2005), Dalil arshadiun liltadrib almaydanii fi almajal almadrasi: Dirasat wasfiat tahliliat mutbaqat ealaa talibat alfirqat althaalithat walfirqat alraabieat fi kuliyat alkhidmat alaijtimaeiati, Majalat Dirasat fi Alkhidmat Alaijtimaeiati, (19), 313-360.

Ashtih, Emad Abdullatif (2009), Mueawiqat alwusul 'iilaa aljawdat alshaamilat fi tatbiq muqararat altadrib almaydanii fi takhasus alkhidmat alaijtimaeiat fi Jamieat Alquds Almaftuhati, Almajalat Alfilastiniat Liltarbiat Almaftuhat Ean Bued, 2(3), 243-290. 
د. ماجد مهدي قاسم القطوي

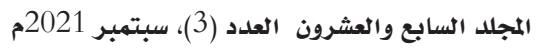

Baghrib, Amani Abdel-Razzaq Ahmed, Bahshwan, Fathia Muhammad Mahfouz, wa Al-Aidarous, Maryam Muhammad (2019), Mueawiqat altadrib almaydanii litalibat alkhidmat alaijtimaeiat bikuliyat albanat Jamieat Hadramut, Majalat Jamieat Hadramawt Lileulum Al'iinsaniati, 16(2), 463491.

Balabel, Magda Ragheb Muhammad (2014), Wahdat muqtarihat limuajahat mushkilat altarbiat aleamaliat litulaab shuebat alfalsafat bikuliyat altarbiat wa'athariha fi tanmiat maharatihim altadrisiata, Dirasat Earabiat fi Altarbiat Waeilm Alnafsi, (52), 101-144.

Fahmy, Mohamed Sayed (2002), Madkhal fi alkhidmat aliajtimaeiati, Al'iiskandiriati: Almaktab Aljamieii Alhadithi.

Hanafi, Abdulghaffar (1993), Alsuluk altanzimiu wa'iidarat al'afradi, Al'iiskandiriati: Almaktab Alearabii Alhadithi.

Harb, Saeed Ibrahim (2009), Almushkilat alati tuajih altaalib almuealim 'athna' altadrib almaydanii wasubul eilajiha, Waraqat eamal fi alyawm aldirasii hawl altadrib almaydanii bayn 'ada' altaalib almuealim watawjihat almushrif altarbawii wal'iidarat almadrasiati, 2 Yuniu, Aljamieat Al'iislamiati, Ghaza, Filastin.

Hegazy, Wagdy Hamed (2010), Altadrib fi alqarn alhadi waleishruna, Al'iiskandaria: Dar Altaelim Aljamieii.

Jaafar, Zainab Abbas (2017), Taqwim altarbiat aleamaliat fi kuliyat aleulum waldirasat al'iinsaniat bihawtat sadir min wijhat nazar altaalibat almuealimati: dirasatan maydaniatan litalibat almustawaa althaamin lileam aldirasii 2017, Majalat Althaqafat Waltanmiati, 17(114), 34-85.

Kurdi, Ahmad Alsayid (Mayu 6, 2010), Mabadi altadrib al'iidari, Astariie bitarikh Yanayir 1, 2021, min https://bit.ly/3BwAid7

Majmae Allughat Alearabia (1993), Almuejam alwujiz, Alqahirati: Alhayyat Aleamat Lishuuwn Almatabie Al'amiriati.

Massoud, Jubran (2003), Muejam Alraayidi, Bayrut: Dar Aleilm Lilmalayini.

Mustarihi, Maha Muhamad (2020), Mueawiqat altadrib almaydanii min wijhat nazar talibat kuliyaat altarbiat fi aljamieat alsaeudiati: Dirasat halat Jamieat Hayl, Majalat Al'iidarat Waltanmiat Lilbuhuth Waldirasati, 9(2), 150-179.

Naghmish, Ahmed Al-Hussein Al-Sayed (2014), Muqtarah litanzim altadrib almaydanii litakhasusat eulum wahandasat alhasibi, Majalat Aitisalat Jameiat Alhasibat Alearabiati, 7(1), 108-135.

Omar, Ahmed Mukhtar (2008), Muejam allughat alearabiat almueasira (Taba'a 1), Alqahiratu: Aalam Alkutub.

Qassem, Mohamed, wa Faramawy, Mostafa (2005), Alkhidmat aliajtimaeiat almadrasiatu, Alqahirati: Maktabat Al'anjilu Almisriati. 


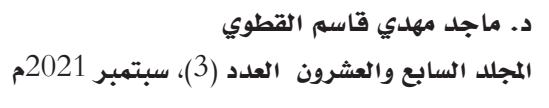

Radwan, Mahmoud Ali Mahmoud (2020), Mueawiqat jawdat altadrib almaydanii litulaab alkhidmat alaijtimaeiati, Majalat Kuliyat Alkhidmat Alaijtimaeiat Lildirasat Walbuhuth Alaijtimaeiati, (21), 413-460.

Ragab, Ibrahim Abdel-Rahman (1988), Asasiaat altadrib almaydanii fi muhit alrieayat alaijtimaeiat waltanmiat alaijtimaeiati, Alqahirati: Maktabat Wahbat.

Saad, Mahmoud Hassan (2000), Altarbiat aleamaliat bayn alnazariat waltatbia (Taba'a 1), Amman, Al'urdunu: Dar Alfikr Liltibaeat Walnashri.

Sadiq, Hoda Ahmed (1993), Tahdid alaihtiajat altadribiat fi alqitae alhukumi, Almajalat Alearabiat Liltadrib, 5(10), 11-33.

Shehata, Essam (2010), Jawdat altadrib almaydanii ka'ahad maeayir alaietimad limaeahid alkhidmat alaijtimaeiati, Majalat Dirasat fi Alkhidmat Alaijtimaeiat Waleulum Al'iinsaniati, (10), 1294-1321.

Shubita, Zarda (2011), Mueawiqat altadrib almaydanii bimajalat almumarasat aleamat fi alkhidmat alaiitimaeiati, Waraqat muqadimat fi Mutamar Dawr Alkhidmat Alaijtimaeiat fi Almujtamae Alfilastinii, 1 Nufimbir, Qism Ealm Alaijtimae Walkhidmat Alaijtimaeiati, Kuliyat Aladab fi Jamieat Alnajah Alwataniati, Nabuls.

Wilz, Mike (2005), Idarat eamaliat altadrib: Wade almabadi mawdie altanfidhi, Tarjamat muhsin 'iibrahim aldasuqi, Alsaeudiat: Maehad Al'iidarat Aleamati.

Yaghi, Muhamad Abdulfattah (2011), Mabadi al'iidarat aleama (Taba'a 2), Amman: Dar Wayil Liltibaeat Walnashri. 